\title{
The Hanklit Glaciotectonic Thrust Fault Complex, Mors, Denmark
}

BY

KNUD ERIK S. KLINT \& STIG A. SCHACK PEDERSEN

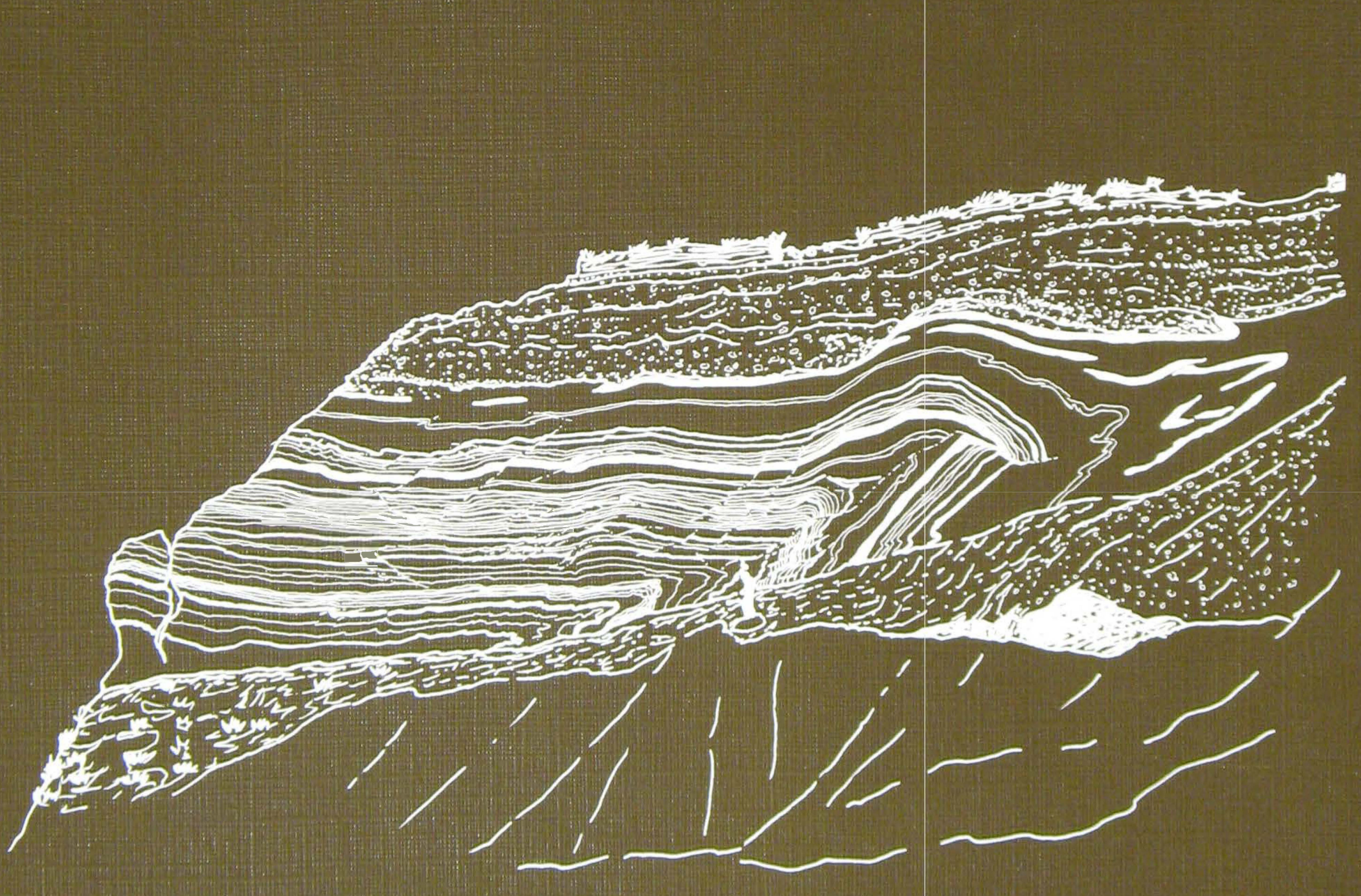

Geological Survey of Denmark • Copenhagen 1995 


\section{The Hanklit Glaciotectonic Thrust Fault Complex, Mors, Denmark}

BY

KNUD ERIK S. KLINT \& STIG A. SCHACK PEDERSEN

Geological Survey of Denmark • Copenhagen 1995 


\section{Key words:}

Hanklit, Mors, Jutland, Denmark, glaciotectonics, Weischelian, thrust sheet, thrust fault complex, Tertiary.

\section{Vignette:}

The Frontal part of the Hanklit Thrust Sheet.

DGU serie A Nr. 35

ISBN 87-89813-23-5

ISSN 0901-0270

Oplag: 1000

Manuskript accepteret November 1994

Tryk: From \& Co.

Sats og repro: DGU grafisk

Tegning: Forfatterne og Helle Zetterwall

Dato: 1.6.1995

Knud Erik S. Klint og Stig A.Schack Pedersen

Geological Survey of Denmark

Thoravej 8

DK-2400 København NV.

Redaktion (Editor): Svend Stouge

(1) Danmarks Geologiske Undersøgelse

Thoravej 8, DK 2400 København NV.

I kommision hos: Geografforlaget ApS

Ekspedition: Fruerhøjvej 43, 5464 Brenderup

Telefon: 64441683 


\section{Contents}

Abstract ..................... 4

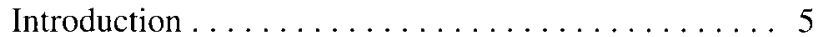

Geological setting ................. 7

Pre-Quaternary setting around the

Thisted Bredning area ............... 7

Quaternary setting around the

Thisted Bredning area .............. 8

Geomorphology ............... 8

Lithology and stratigraphy $\ldots \ldots \ldots \ldots \ldots \ldots \ldots \ldots$

The Fur Formation . . . . . . . . . . . . . . . . 10

The Hanklit glacigene group . . . . . . . . . 11

Structures. . . . . . . . . . . . . . . . 12

Descriptions of the main structural elements . . . . . 12

The Gullerup Thrust Sheet . . . . . . . . . . . . . 12
The Hanklit Thrust Fault. . . . . . . . . . . . . . . . . . 12

The Hanklit Thrust Sheet . . . . . . . . . . . . . . . . . 14

The Salgerhøj Thrust Sheet . . . . . . . . . . . . 17

Balanced cross-section . . . . . . . . . . . . . . . 20

The 3-dimensional framework of the

Hanklit Thrust Fault Complex . . . . . . . . . . 22

The structural development of the

Hanklit Thrust Fault Complex. . . . . . . . . . . . . . 23

Pre- glaciotectonic deformation . . . . . . . . . 23

Discussion ....................... 26

Glaciodynamic sequences .............. 26

Glacial Stratigraphy . . . . . . . . . . . 27

Summary and conclusions. . . . . . . . . . . . . . . 28

Acknowledgements ................... 30 


\section{Abstract}

The Hanklit cliff section is a classical glaciotectonic locality where an excellent cross-section through a thrust fault complex is exposed. The thrust imbrications were thrust from north to the south during a Late Weichselian glacier advance.

Three thrust sheets with thickness of more than $50 \mathrm{~m}$ are involved in the thrust fault complex. The deposits exposed in the cliff-section comprise ca. $39 \mathrm{~m}$ diatomite with ash layers of Paleocene-Eocene age (the Fur Formation), overlain by up to $27 \mathrm{~m}$ of Quaternary glacigenic sediments.

Common structural features related to compressional thrust fault belts, are recognizable in the glaciotectonic complex, which shows a lateral shortening of more than $40 \%$.

Structures created by soft sedimentary deformation due to high water pressure occur in relation to the thrust fault zones.
The structural framework is described with the terminology of thin-skinned tectonics and flats, ramps and hanging-wall anticlines are identified in the cliff-section

A balanced cross section has been constructed. Based on this construction the structural model is verified and the glaciotectonic development is interpreted.

A geoelectrical investigation has been made to support the construction of the 3-dimensional framework of the thrust complex. This demonstrates that the impressive Hanklit thrust sheet extends for more than $1 \mathrm{~km}$ along the strike and is displaced more than $200 \mathrm{~m}$ to the south.

Superimposed extentional structures, situated above the sole of the Hanklit Thrust Sheet, are interpreted to be related to Tertiary subsidence tectonics. 


\section{Introduction}

During the late Weichselian ice advance from Norway and Sweden towards the Main Stationary Line in Jutland, a number of large glaciotectonic complexes were formed in the northern part of Jutland (Ussing, 1913; Jessen, 1918, 1931; Gry, 1940, 1979, Gry et al., 1941). In the western Limfjorden region these glaciotectonic complexes are par- ticularly significant and enhance to the geomorphological modulation of the landscape with marked elongated hills outlining the push moraine ridges (fig. 1).

One of the striking points in the development of these glaciotectonic complexes is the involvement of Tertiary clay, formations in the glaciotectonic deformation (Gry, 1940).

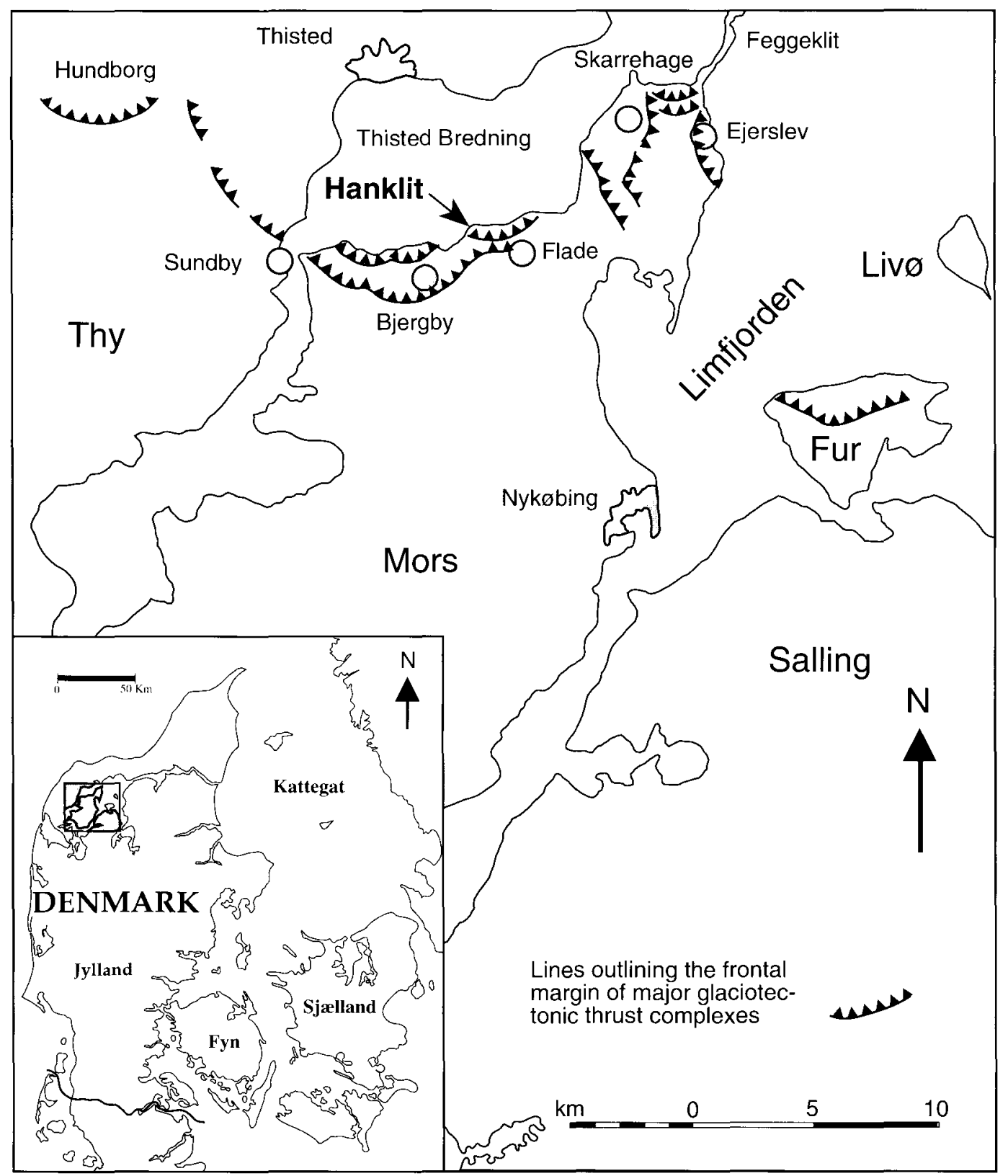

Fig. 1. Location map of the Hanklit Thrust Fault Complex. Hanklit is a cliff section, displaying a geological cross section, showing one of the composite ridge systems characteristic of the western Limfjorden region in $N W$-Denmark. The composite ridge systems are com-piled from Gry (1940, 1979). 
On the island of Mors several well exposed coastal cliffs and clay pits profiles provide good opportunities to study the internal framework of the glaciotectonic structures.

One of the most famous localities is the Hanklit cliff section on the north coast of Mors (fig. 2, enclosed as fold out plate in the back of this paper). Here, the NE-facing coastal cliff exposes a cross-section through the central part of a large composite ridge system.

The large composite ridge system at "Flade Klit", which constitutes the elongated ridges east of Hanklit, was classified as a type locality of large composite ridge systems by Aber, Croot \& Fenton (1989).

The structures of Hanklit may be regarded as a meso-scale thin-skinned thrust fault belt. In this respect the Hanklit glaciotectonic complex is one of the best examples of the comparability of glaciotectonics and hardrock structural geology as described by Banham (1988), Berthelsen (1978, 1979), Croot (1987), Pedersen (1987) and Aber, Croot \& Fenton (1989). The Hanklit thrust system exhibits typical features related to foreland thrust fault and fold systems such as ramp and flats, décollement planes and individual thrust sheets as noted by Aber, Croot \& Fenton (1989, p. 173), Boyer \& Elliott (1982) and Butler (1987).
In this paper a detailed structural analysis of the Hanklit Thrust Fault Complex is presented. A model of the 3-D framework is based on geoelectrical profile mesurements of the thrust sheet in the field between Hanklit and Salgerh $\phi j$ and the detailed survey of the cross section exposed in the coastal cliff section.

One of the important things in the construction of a structural model is to check the validity of the structural profiles. This control is excellently provided by the construction of a balanced cross section (Dahlström, 1970; Suppe, 1985). During the construction of the Hanklit cross section a new interpretation of the position of the décollement surface and the geometry of the main thrust faults was developed. This necessitated a revision of the former structural model of the thrust fault complex given by Jensen \& Pedersen (1989).

Finally a model for the glaciodynamic development of the Hanklit Thrust Fault Complex is discussed in relation to the concept of glaciodynamic sequence stratigraphy (Pedersen, 1993). 


\section{Geological setting}

\section{Pre-Quaternary setting around the Thisted Bredning area}

The Pre-Quaternary geology of the western Limfjorden region is dominated by a number of salt structures (Hansen \& Håkansson, 1980; Larsen \& Baumann, 1982; and Madirazza, 1990).

The Hanklit Thrust Fault Complex is situated between two of these structures. To the north the Thisted Salt pillow forms a flat-topped shield with upper Maastrichtian chalk cropping out in the center and along the southern flank.

To the south, the steeply rising salt diapir of the Erslev salt structure is capped by bryozoan limestone of lower Tertiary age (Danian limestone).

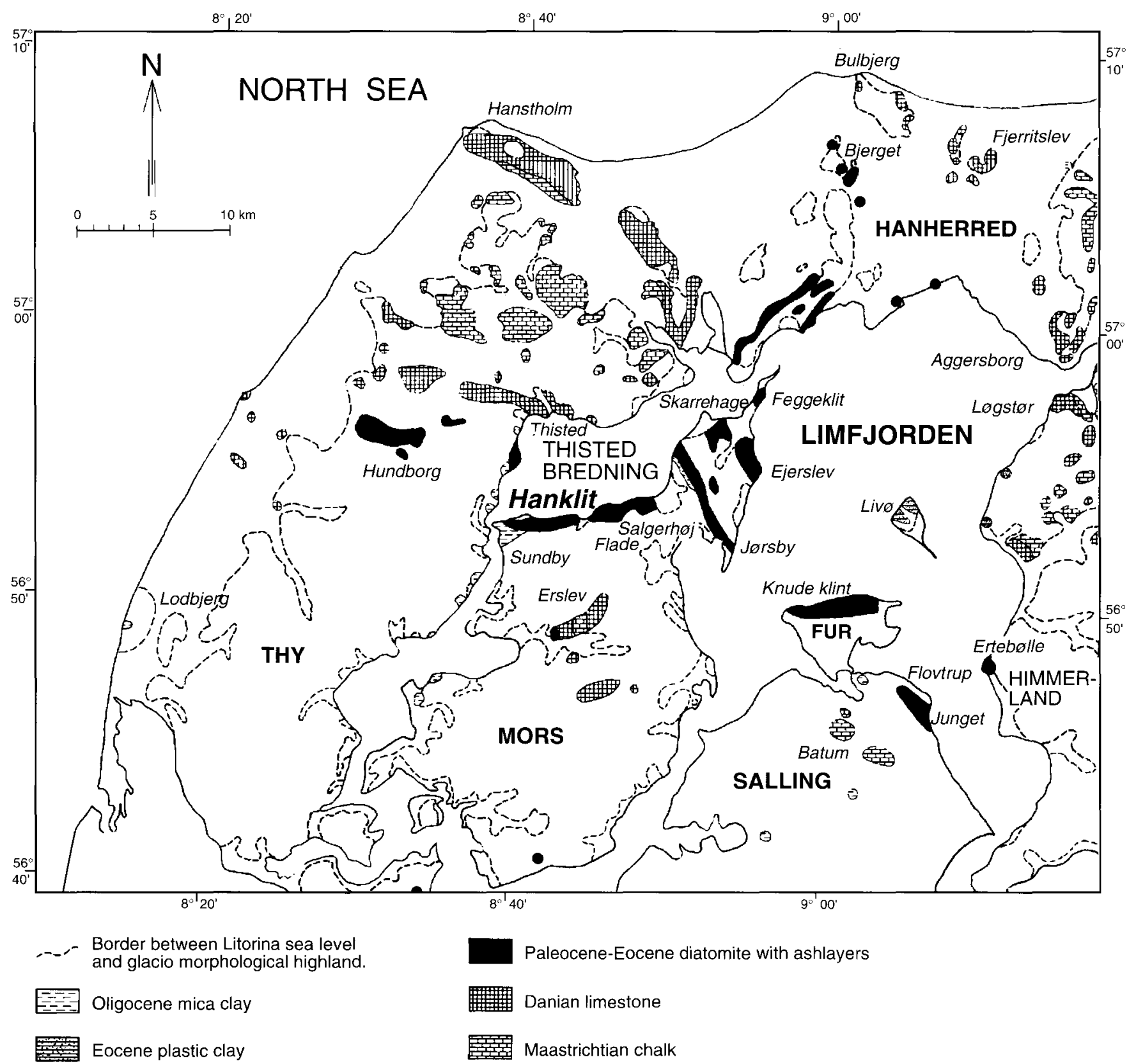

Fig. 3. Outcrops of pre-Quaternary sediments in the western Limfjorden area. Note that the Hanklit locality is situated between the Thisted saltdome to the north and the Erslev saltdiapir to the south. These deep seated structures are indicated by the occurrences of Maastrichtian chalk. 
Between the Thisted salt structure and the Erslev Salt structure the sediments form a depression under northern Mors, and successive sedimentary sheets of Paleocene, Eocene and Oligocene age crop out on the surface due to glaciotectonic upthrusting (fig. 3) (Pedersen, 1989).

Paleocene diatomite with interbedded ash layers is the most characteristic unit in these outcrops and is considered to have been deposited in a shelf sea at moderate depth under low energy conditions (Pedersen \& Surlyk, 1983; Pedersen, 1981; Bonde, 1979).

The sediment is differentiated into laminated and structureless diatomite, reflecting anoxic and oxic conditions respectively. In the structureless diatomite the trace fossil Teichichnus is fairly abundant (Pedersen, 1981).

A rich fauna of fish and insects are found in the diatomite, as well as leaves and petrified wood, which occur abundantly in some levels of the diatomite.

It is difficult to estimate the geographical extension of the diatomite-sea, but it might have been restricted to a local basin formed as a result of tectonic subsidence and local halokinesis.

Numerous volcanic eruptions from a volcanic center in the North Atlantic region, supplied the diatomite with volcanic ash (G.K.Pedersen, 1981; S.A.S.Pedersen, 1990; Nielsen \& Heilman-Clausen, 1988; Andersen, 1944).

A major unconformity in the main part of the Eocene and lower Oligocene dominates the local area around Thisted Bredning. This hiatus is probably the result of differential movements in the salt diapir structures. The Oligocene beds above the diatomite concist of dark micaceous mudstone.

During the Miocene the region was an area of nondeposition due to the Neogene uplift of northern Denmark and erosion has taken place ever since (Japsen, 1992).

\section{Quaternary setting around the Thisted Bredning area.}

The Quaternary geology of the western Limfjorden region is dominated by glaciodynamic features of the late Weichselian ice advance.

Occurrences of pre-Weichselian Quaternary deposits are recorded from a few isolated localities, where sediments have been trapped in the Weichselian raft-complexes.

Elsterian tills at Thyholm south of Mors are the oldest record of a Quaternary glaciation in the area (Ditlefsen, 1987).

At Kaas Hoved and at Flovtrup on Salling, Holsteinian marine to glaciomarine dark mud indicate that at least a part of the western Limfjorden area was transgressed by the interglacial Holsteinian sea (Jensen \& Knudsen, 1984; Pedersen, 1990).

Tills of Saalian ages are known from a number of wells in the area and are found along the coastal cliffs of Mors, as for instance Feggeklit (Pedersen, 1993). No evidence of Eemian deposits has been recorded, but a number of glacio-lacustrine occurrences indicate that the pre-Late Weichselian landscape had very rough topography with a great variety of relief.
The Main ice advance in the late Weichelian was from the north (Gry, 1940, 1979). Numerous indicator boulders of larvikite and rhombeporphyry occur throughout the landscape and along the beaches, clearly documenting ice transport from the Oslo region in southern Norway (Milthers, 1909; Noe-Nygaard, 1992).

Prior to the Late Weichselian ice transgression a variety of sandur deposits existed in the foreland of the ice margin. Permafrost conditions prevailed in this period, as evidenced by ice wedge casts which penetrate the meltwater sediments (Pedersen \& Petersen, 1985a).

During the Main ice advance from the north towards the Main Stationary Line to the south (about 20.000 BP (Petersen \& Kronborg, 1990)), most of the impressive glaciotectonic complexes were formed by the advancing ice which transgressed the ridges, truncated the structures and deposited the uppermost till in the area (Pedersen \& Petersen 1985b; Pedersen, 1993).

During the regression of the ice a few readvances modified the glaciotectonic hills (Pedersen, 1992). Ice movement directions from the northeast correspond well with the record of a shift in general ice movement direction from north to northeast, documented by the till fabric analysis of the deposits in the Bovbjerg cross-section at the Main Stationary Line ( Pedersen et al., 1989).

In the Latest Weichselian the Limfjorden was first formed as an incised valley system. During the Atlantic transgression the Western Limfjorden region formed an archipaelag (Gry, 1979).

The isostatic rise of Northern Jutland during the postglacial and Holocene (Petersen, 1985) formed the beach ridge peninsula and landstrips connecting the islands.

The recent coastmorphology is characterised by numerous landslide processes activated by a combination of high relief, suitable lithologies for sliding (clays) and the common humid weather in the region (Pedersen, 1987, 1992; Pedersen et al., 1990).

\section{Geomorphology}

Most of the northern part of Mors is covered with Quaternary sediments.

Pre-Quaternary sediments are only exposed where they occur in association with glaciotectonic structures.

The dominating landforms are:

1. Ice-shoved hills.

These areas are dominated by elongated parallel hills striking east-west with a large relief (up to $89 \mathrm{~m}$ above sealevel at Salgerhøj).

The hills are partly constructed of dislocated or folded sequences of Tertiary sediments.

2. Hummocky moraine landscape.

This area is dominated by well-rounded hills of low relief which mainly comprise glaciofluvial sediments with a cover of till. This landscape most probably represents ice- 
overridden out-wash plains. There seems to be a general pattern in several areas with fining upward fluvial sediments overlain by glaciolacustrine clay, generally covered by a clayey till.

The geomorphological map on fig. 4 shows the characteristic ice shoved ridge systems of Northern Mors. The map is based on analysis of acrial photographs and topographic maps. By outlining the the hill crests and the elongated valleys, the significant parallel linear patterns and the arcs are clearly demonstrated (fig. 4).

Four pronounced areas form the systems and are refered to as the Mosebjerg Arc, the Strerhøj Arc, the Bjergby Arc and the Hanklit-Salgerhøj Arc (Molerindvinding på Mors, 1985)

\section{The Hanklit-Salgerhøj area:}

The Hanklit-Salgerhøj Arc forms the most characteristic push-ridge system on the northern part of Mors.

The range of hills, approx. 3,5 km long and 1,5-2 km wide, describes a broad arc of several parallel elongated hills, with a topographic relief from the Pre-Quaternary surface below Thisted Bredning of about $100 \mathrm{~m}$ to the top of Salgerhøj ( $89 \mathrm{~m}$ a.s.1.).

The individual ridges generally have steep southern flank up to ca. $15^{\circ}$, and a less steep northern flank. The hills are most pronounced in the northern part, and become more smooth to the south.

Meltwater-channels and elongated glaciolacustrine basins formed in the topographically low areas.

In the southern part of the area three pronounced spillways intersect the southernmost hill, crosscutting the push ridge (fig. 4).

The central part of the area is strongly disturbed as a result of extensive landsliding (Pedersen, 1987, 1992).

The intensive landsliding indicates the presence of oblique sediment-sheets in the hills, and each range of hills are interpreted to represent either a dislocated thrust sheet or an anticline in the folded sediment-package.

Steeply dipping ash layers and calcerous concretions in the sea floor near the shore, further outline the trend of the composite ridge system; which in so many respects may be called a glaciotectonic mountain chain, according to the comparative description in Aber, Croot \& Fenton (1989 p. 31).

The number of hill-ridges vary from approx. seven in the eastern part of the push ridge complex area, to three at Hanklit.

On aerial photographs it is seen that the hills at Hanklit shows a considerable low degree of roundness compared to the hills in the southwestern area, the so called "Bjergby arc" (fig. 4).

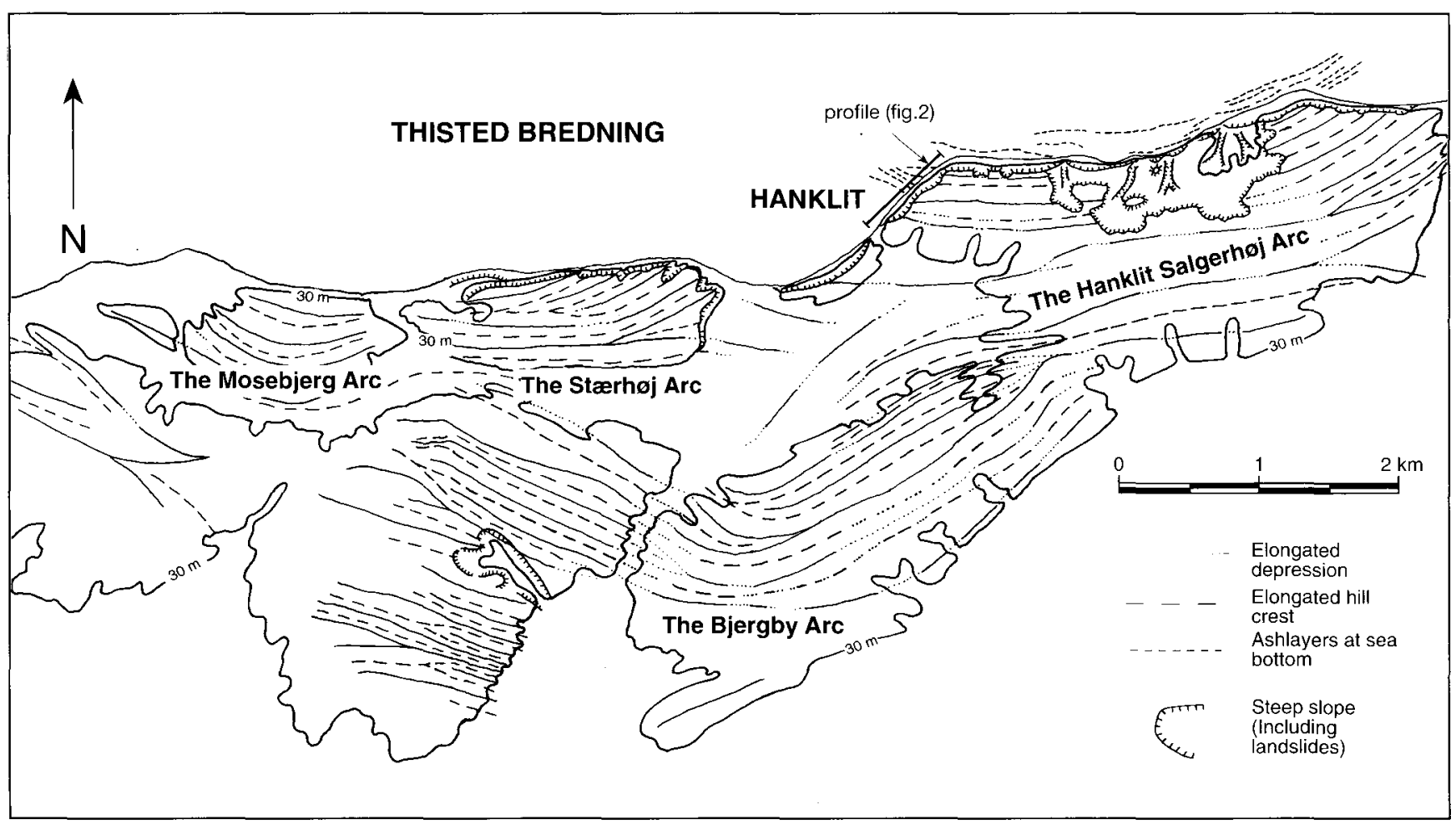

Fig. 4. Geomorphological map of the central and western part of northem Mors. Note that the Hanklit-Salgerhoj arc and the Bjergby arc form the proximal and distal part respectively of the composite arc system. For the topographical orientation the $30 \mathrm{~m}$ contour line is drawn. The Map is based on interpretation of topographic maps and aerial photographs. 


\section{Lithology and stratigraphy}

The deformed sediments in the Hanklit Thrust Fault Complex consist of two large lithostratigraphic units: The lower Tertiary Fur Formation and the Hanklit glacigene group, (fig. 5).

\section{The Fur Formation}

The Fur Formation is a Palaeogene diatomite interbedded with volcanic ash layers.

It is divided into the lower Knudeklint Member, with the

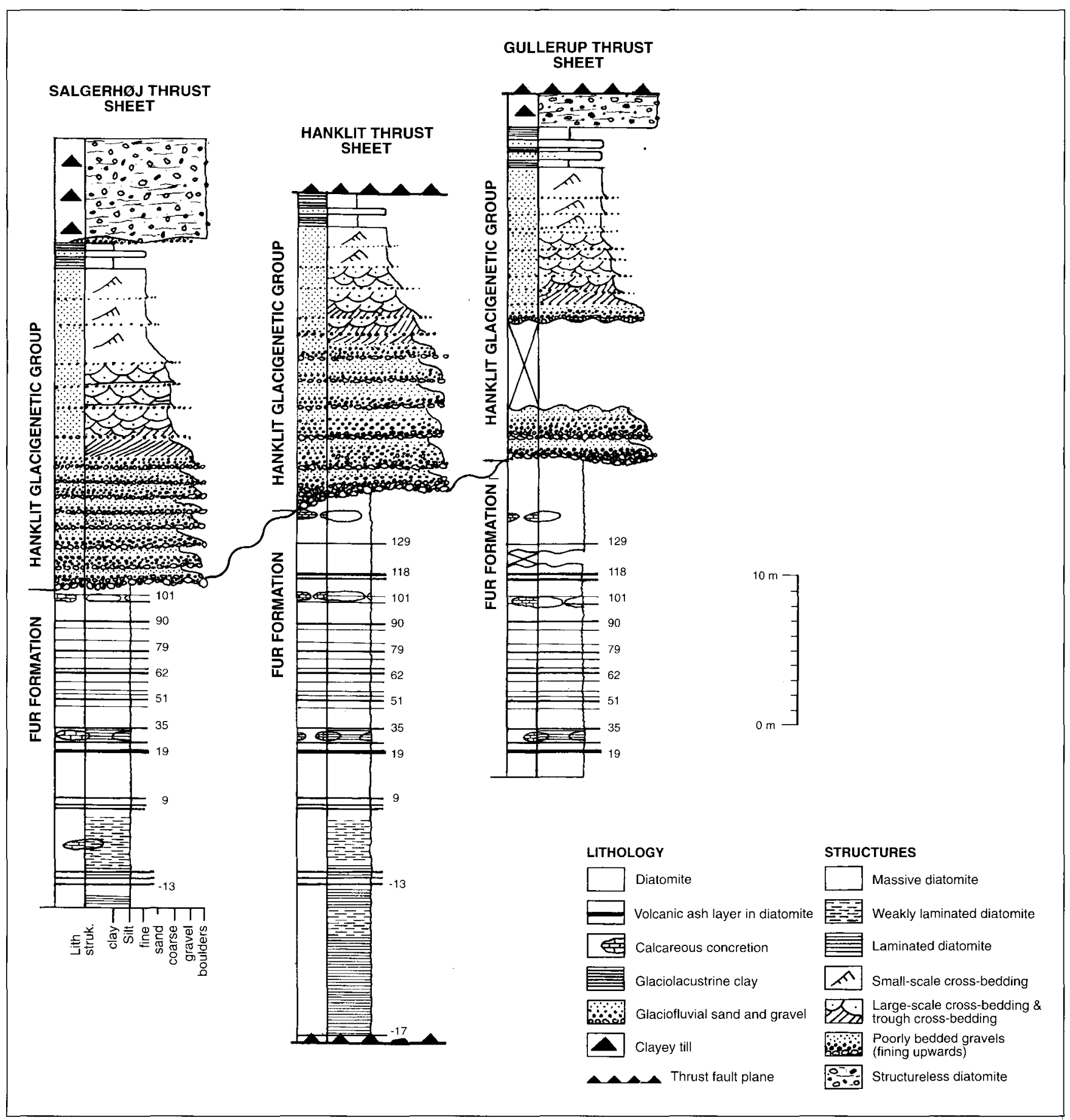

Fig. 5. Three lithological sections representing the stratigraphical units included in the Hanklit Thrust Fault Complex. 
negative numbered ash layers, and the upper Silstrup Member with the positive numbered ash layers (Pedersen \& Surlyk, 1983; Bøggild, 1918).

\section{Diatomite:}

The diatomite, locally known as "mo-clay", is a non-calcareous dark-grey marine sediment, which weathers into light yellowish-grey colour. It consists of the frustules of marine diatoms, ca. $0,02-0,2 \mathrm{~mm}$ in size and clay minerals, mainly montmorillonite, which make up approx. 35\% of the sediment (Pedersen 1981). The mo-clay is highly porous and has an average density of $0,8 \mathrm{~g} / \mathrm{cm}^{3}$ (Pedersen \& Surlyk, 1983).

The structure of the diatomite changes throughout the type section from massive to weakly laminated and well-laminated. The laminated structures represents periods of anoxic events during the sedimentation of the diatomite (Pedersen, 1981).

Ash layers:

A number of volcanic ash layers are interbedded in the moclay. These ash layers were described and measured by Bøggild (1918), who is responsible for the numbering of each ash layer, and the division into the positive and negative ash layer series.

In total, 179 ash layers numbered from -39 to +140 were measured. At Hanklit ash layer number -17 to +130 appear in the mo-clay.

The thickness of the ash layers varies from less than $1 \mathrm{~cm}$ and up to ca. $20 \mathrm{~cm}$, and the colour varies from black to grey-blue. The grain size ranges from silt to fine sand with a typical normal grading.

These ash layers provides an excellent opportunity for stratigraphic correlation from one thrust sheet to the next.

\section{Calcareous concretions:}

Calcareous concretions are found at certain levels in the diatomite. They are usually ellipsoids with a maximum size of $1,5 \times 0,4 \mathrm{~m}$, but a continuous layer approximately $30 \mathrm{~cm}$ thick occurs around ash layer +101 . Compaction of the diatomite around the concretions in the Hanklit area suggests a relatively early diagenetic age.

\section{The Hanklit glacigenic group}

The Quaternary sediments at Hanklit are separated into glaciofluvial to glaciolacustrine deposits and an overlying till (fig. 5).

\section{Glaciofluvial facies}

The glaciofluvial facies comprise a 10 - 17 m thick sequence of gravel with clast sizes up to $20 \mathrm{~cm}$ diameter, overlain by $8-15 \mathrm{~m}$ of coarse to fine sand.

The whole section comprises a generally fining upwards sequence, with plane-bed lamination in the lower part suc- ceeded by large scale trough cross-bedding and planar cross-bedding to small-scale ripple-structures in the uppermost fine sand.

Some of the boulders in the lowest part of the section are rhombeporphyry and larvikite, indicating a glacigene source area in the southern part of Norway, and palaeo-current measurements of the cross-bedding showed a general current direction from north - north-east towards south south-west.

\section{Glaciolacustrine facies}

The glaciolacustrine deposits overlie the glaciofluvial sediments, and consist of two or three 10 to $>100 \mathrm{~cm}$ thick grey massive clay-beds, interbedded with layers of fine structureless light yellow sand/silt.

Due to intense tectonism, which occured during the deposition of the overlying till and subsequent thrusting, the deposits appear strongly sheared and the pre-deformational sedimentary thickness of the deposits is difficult to determine.

\section{The till}

The till is a massive, clayey till with some silt, sand, gravel and few stones, mainly flint and chalk. The colour is dark olivegrey to olivebrown, and the chalk-content in the matrix is between 8,5 and $10,5 \%$ by weight.

The till overlies the lacustrine clay in the northern upper part of the cross-section (fig. 2), and in the central and southern part of the cross-section. It defines the boundary between the Palaeogene sediments and the Quaternary sediments wherever it appears.

The till is classified as a subglacial lodgement till (Jensen, 1992).

In order to establish a correlation between the different occurrences of the till at Hanklit and the wider stratigraphic correlation between other tills in the Thisted Bredning area, 6 samples of the till were collected, and finegravelanalysis after the dutch method (Ehlers, 1979) was carried out (fig. 6).

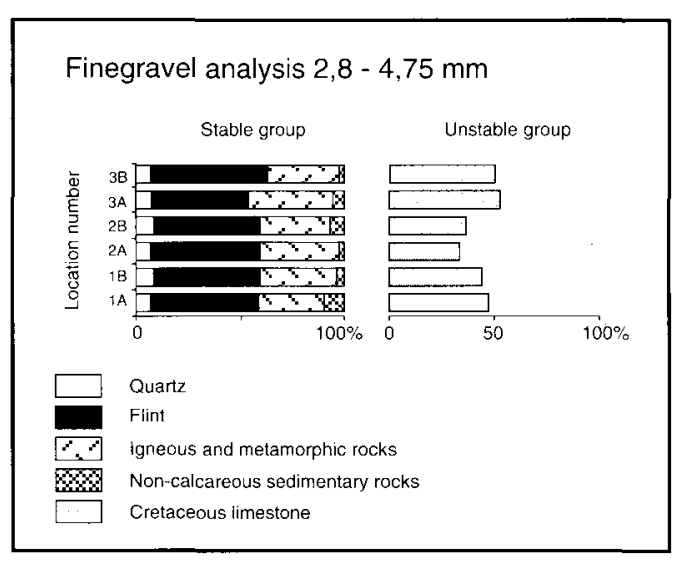

Fig. 6. Fine gravel analysis of the tills located in the top of the Salgerhoj Thrust Sheet $(I A, I B, 2 A$ and $2 B)$ and in the top of the Gulle rup Thrust Sheet ( $3 A$ and $3 B)$. 


\section{Structures}

\section{Descriptions of the main structural elements}

The cross section exposed in the Hanklit cliff displays an imbricated glaciotectonic thrust fault system, consisting of two thrust sheets, which have overthrust the foreland to the south.

The following tectonostratigraphic units are erected: We have chosen to call the main thrust sheet, which makes up most of the cross-section "the Hanklit Thrust Sheet". This has been thrust across the foreland to the south along "the Hanklit Thrust Fault".

The foreland forms an elongated ridge, parallel to the ridge forming the Hanklit Thrust Sheet, and is regarded to be a separate flatlying thrust sheet, possibly limited by a blind thrust fanning out in the subsurface to the south.

We call this foreland feature "the Gullerup Thrust Sheet" after the little village south of Hanklit.

We use the term "The Salgerhoj Thrust Sheet" to describe the northernmost thrust element, after a diatomite profile at the coast approx. $1,5 \mathrm{~km}$ east of Hanklit, described by Håkansson \& Sjørring (1982).

It is thrusted across the Hanklit Thrust Sheet along "the Salgerh $\phi j$ Thrust Fault".

In Fig. 7 the main notations of the structural elements applied in this study are illustrated, and the orientation of the stratigraphical bedding shows an ice-push direction from the north towards the south .

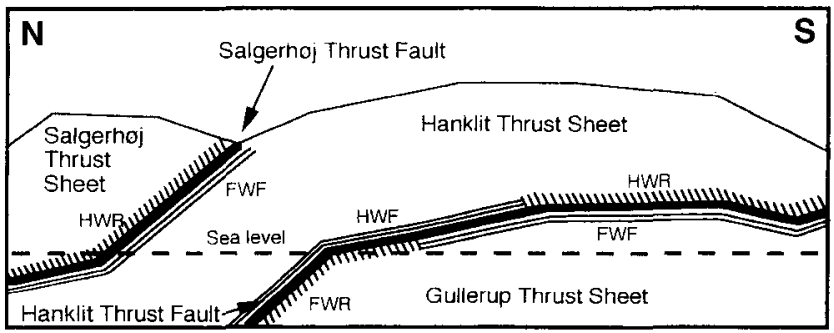

FWF: FOOT-WALL FLAT FWR: FOOT-WALL RAMP HWF: HANGING-WALL FALT HWR: HANGING-WALL FLAT

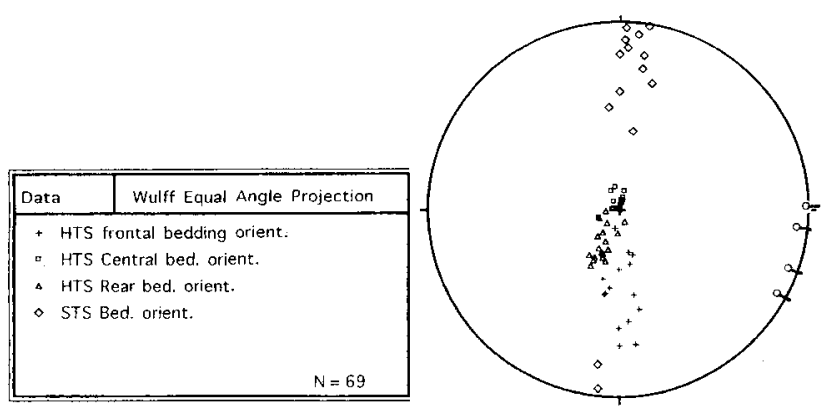

The following descriptions of the thrust sheets are closely related to the geological section shown in fig. 2, and special structures are located in relation to their position on the baseline of this section.

\section{The Gullerup Thrust Sheet}

The Gullerup Thrust Sheet forms the southernmost part of the Hanklit Thrust Complex, and it may be regarded as the foreland to the Hanklit thrusting. The deposits in the Gullerup Thrust Sheet are exposed in a cliff section approximately $100 \mathrm{~m}$ south of the Hanklit profile (fig. 2). Here the uppermost $14 \mathrm{~m}$ of the Fur Formation appears overlain by the meltwater gravel. However most of the outcrop is obliterated by landsliding and erosion and therfore not included in fig. 2.

The glacigene sediments in The Gullerup Thrust Sheet are tectonically deformed in the upper $10-15 \mathrm{~m}$. The structures are related to deformations directed from the north to the south and are dominantly related to overthrusting of the Hanklit Thrust Sheet.

The Gullerup Thrust Sheet makes up the foot-wall block in the frontal part of the thrust-system, and forms the southern boundary in the Hanklit structure.

In the central-southern part of the section, between 365 $450 \mathrm{~m}$ (ref. fig. 2), the sheet comprises a weak anticlinal fold with a culmination around $410 \mathrm{~m}$. From $410 \mathrm{~m}$ the top side of the block strikes $112^{\circ}$ and dip $14^{\circ}$ to the NE. At 340 $\mathrm{m}$ the Gullerup Thrust Sheet becomes almost horizontal.

\section{The Hanklit Thrust Fault}

The Hanklit Thrust Fault comprises a deformation zone up to five metres thick. The main décollement zone is situated just below the ash layer -17 . The diatomite of the Fur Formation is not directly involved in the shear zone. Below the detatchment between the diatomite and the glacigene sediments a number of features related to the shear zone appear.

Fig. 7. The definition of the structural elements related to thinskinned thrust fault tectonics applied to the Hanklit Thrust Fault Complex. The bedding orientation of the Hanklit and Salgerh $\phi j$ Thrust Sheets strikes allmost east-west indicating a maximum stress direction in a north-south direction. The Hanklit Thrust Fault Complex is thus interpreted formed by a glacier transgressing the area from north. 
In the most distal part of the thrust fault a marked splay splits the thrust up into a listric thrust fault, steepening up into the large frontal anticline of the Hanklit Thrust Sheet. The other branch of the splay thrust fault bends into a horizontal position and disappears into the meltwater gravel in the recumbent limb of the large frontal anticline.

An overturned fold structure, deformed from the north towards the south appears at $40.5 \mathrm{~m}$. This structure involves convolution and water escape structures related to the lithological difference between the till and the underlying glaciolacustrine clay interbedded with fine-grained sand. The structure is in the final phase of thrusting dragged along the Hanklit Thrust Fault (fig. 2).

Between 345 and $365 \mathrm{~m}$, a "duplex" structure (Boyer \&

\section{A}

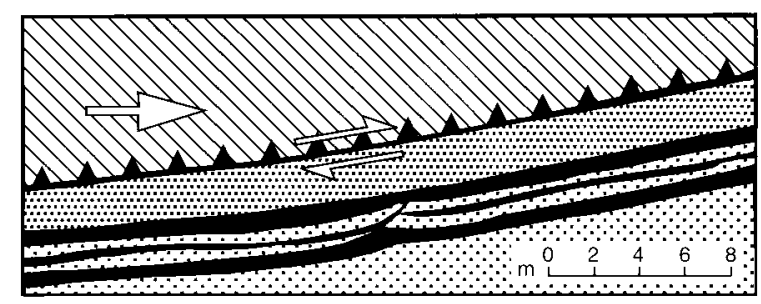

B

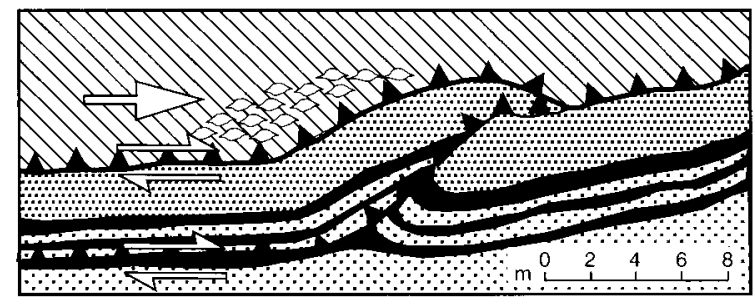

C

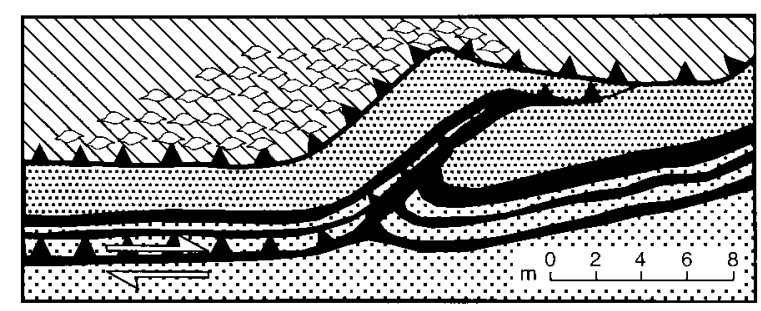

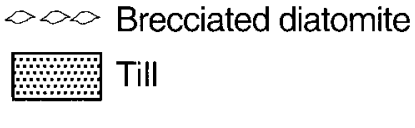

Clay

Fig. 8. Model for the development of the duplex structure at $350 \mathrm{~m}$ : A. A secondary thrust plane develops below the Hanklit Thrust.

$B$. The duplex thrust sheet is thrusted along the new formed thrust plane. Above the main thrust fault the diatomite starts to brecciate against the new obstacle.

C. The displacement cease along the main thrust fault and is shifted to the new thrust fault. Due to the ramping the characteristic feature is formed.

Elliot, 1982) ca. $5 \mathrm{~m}$ thick and $15 \mathrm{~m}$ long, has been formed by complex thrusting of the till and the uppermost part of the glaciolacustrine beds. The structure developed in relation to a former ramp in the Hanklit Thrust Sheet.

First a secondary thrust fault developed below the Hanklit Thrust Fault in the underlaying claybeds. At a later stage, the block was thrust up over a newly formed ramp, displacing the foot-wall flat of the Gullerup Thrust Sheet. (For further explanation of this detail see fig. 8).

Gry (1940) and Ussing (1913) interpreted the duplex structure as result of normal faulting due to settling of the sediments after the thrust phase. However a detailed study of the structure, after a new exposure appeared on the cliff section, enabled us to re-evaluate these interpretations and provide a more comprehensive solution.

From $345 \mathrm{~m}$ the foot-wall block continues, striking $109^{\circ}$ with a weak dip $\left(10^{\circ}-20^{\circ}\right)$ to the north until ca. $255 \mathrm{~m}$ where the Gullerup Thrust Sheet disappears below sealevel.

Chaotic structures related to soft sediment deformation occur in the proximal part of the thrust zone from 265 to $285 \mathrm{~m}$ (fig. 9).

These structures constitute the upper part of foot-wall ramp. The ramp continues to the south, where the first occurrence of the till marks the transition to the foot-wall flat.

Tectonic layering developed by shearing along parallel, secondary thrust planes border rhombohedral segments of the glacigene sediments, thus forming a meso-scale duplex. Furthermore low-angle slip planes between the secondary and the main thrust plane appears in the southern part of this section. The details of the formation of these structures are explained in fig. 10.

Additional liquefaction and intrusion of the clay have formed the slumplike structure in the northern part of the section, which suggest that the lithologies were not permafrozen during deformation.

The Hanklit Thrust Sheet constitutes the hanging-wall block, and ash layer -17 is clearly visible approx. 15-25 $\mathrm{cm}$ above the thrust fault over a distance of more than 100 m. This part makes up the Hanging-wall flat and thus marks the level of the décollement-plane.

The large difference in competence between diatomite, sand and clay are shown by the deformation-pattern in the sediments following the thrusting.

The sand and clay is deformed in a zone more than $5 \mathrm{~m}$ thick, while the diatomite has hardly any internal deformations. Only the lowermost $20 \mathrm{~cm}$ are intensely sheared, as demonstrated by the well-developed slickensides and harnisk-surfaces in the shear-direction, and high pressure transformation of the laminated diatomite into a black glassy compact lithology.

A series of characteristic normal faults cut the diatomite at steep angles. Gry (1940) regarded these as a result of sett ling of the sediments after thrusting. 


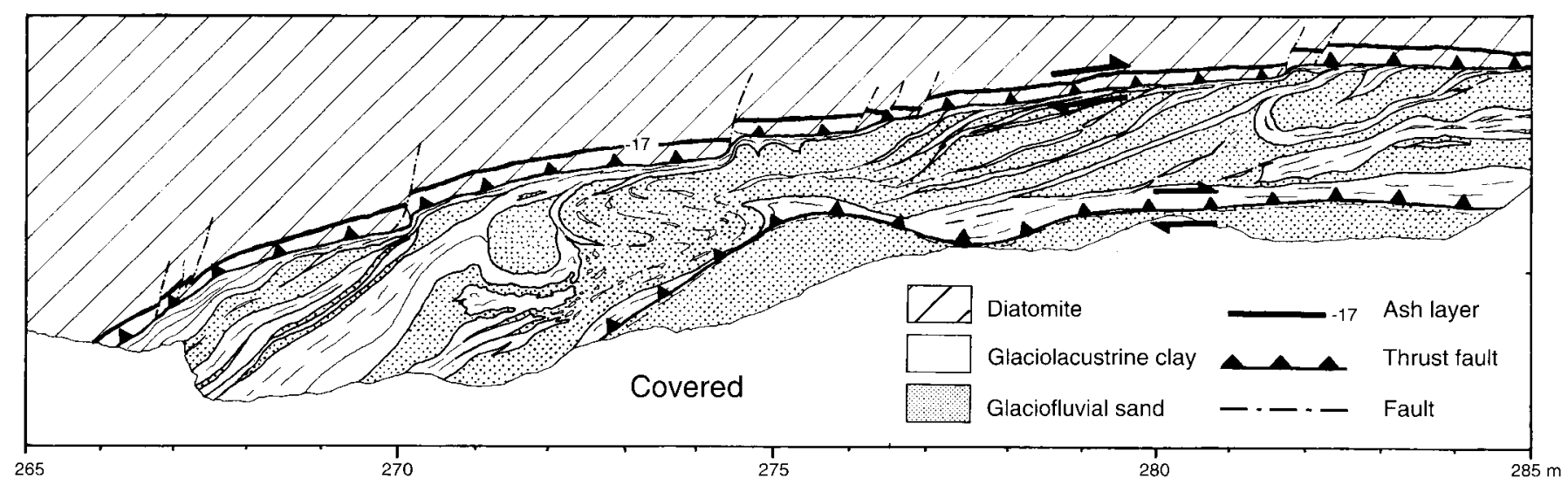

Fig 9. Detail of the structures in the Hanklit Thrust Fault zone, profile situated between 265-285 $m$ (for location see Fig. 2). The formation of the thrust zone is the result of a secondary thrust plane developed below the main thrust plane. Inclined slip planes in the right part of the profile are formed between the two thrust planes and may be described as duplex-like structures. These structures have been subjcted to simple shear whereby the slip-planes have been rotated towards more lowangle inclinations. In the left side of the profile a complex $S$-shaped feature is interpreted as formed by a combination of differential shearing and intrusive mud-diapirism.

Note the steeply dipping normal faults above the thrust zone. These faults are truncated by the thrusting and thus interpreted as preglaciotectonic structures.

The normal faults are however cut by the transition to the thrustplane forming the upper boundary of the Gullerup Thrust Sheet, thus indicating that the normal faulting predates the end of the thrusting along the Hanklit Thrust Fault.

A

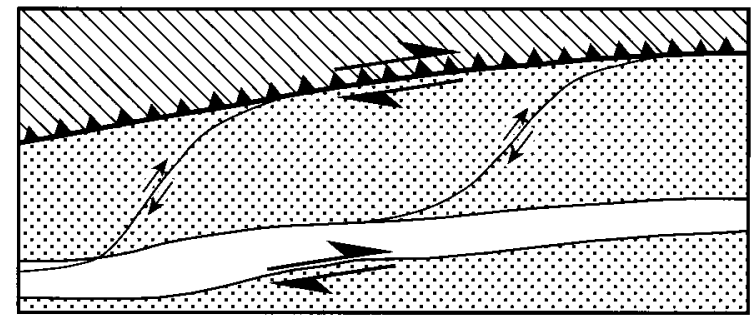

B

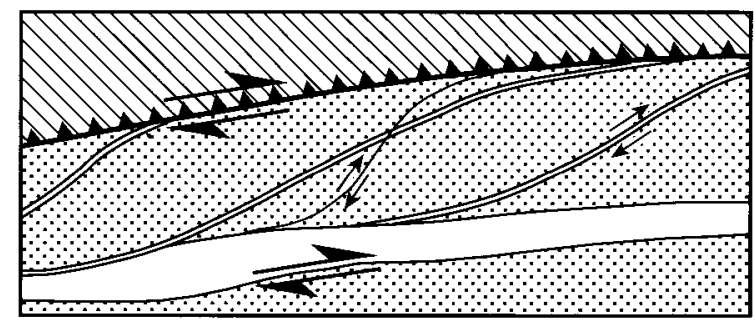

C

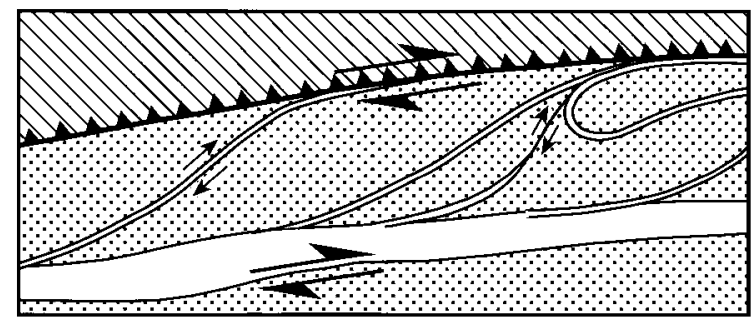

Sand

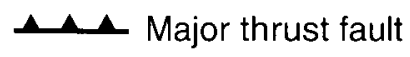

Clay

Seondary thrust fault

Diatomite

Minor slip plane

\section{The Hanklit Thrust Sheet}

The Hanklit Thrust Sheet is approx. $60 \mathrm{~m}$ thick and more than $300 \mathrm{~m}$ long perpendicular to the main fold axes.

The Hanklit Thrust Sheet includes the Fur Formation sediments, from ca. $20 \mathrm{~cm}$ below ash layer -17 to ca. $3-4 \mathrm{~m}$ above ash layer 130, and the glacigenic facies (except the till, which is nowhere visible in the Hanklit Thrust Sheet).

The sheet has been thrust more than $200 \mathrm{~m}$ across the Gullerup Thrust Sheet, and forms from 420 to $490 \mathrm{~m}$ a frontal overturned to recumbent anticlinal fold.

In the central part, the Hanklit Thrust Sheet is almost horizontal, while it forms a ESE striking NNE dipping monoclinal fold in the rear part.

The hanging-wall flat of the thrust sheet is situated just below ash layer -17 . This plane defines the décollementplane for the thrust system. At $330 \mathrm{~m}$, ash layer -17 disappears and the thrust-plane begins to cut up through the thrust sheet whereby the hanging-wall ramp is formed.

The Quaternary sediments are unconformably deposited on the Fur Formation sediments. Major low-angle reverse faults cut from the Fur Formation, into the glacio-fluvial gravel. However all other deformations seems to disappear as internal deformation in these sediments.

The frontal part of the Hanklit Thrust Sheet is folded in a general overturned to recumbent anticlinal fold with an east-west horizontal fold-axis.

Fig. 10. Three stages in the development of the thrust zone displayed in Fig. 9.

A. Initial formation of the oblique slip planes between the main Hanklit Thrust and the secondary thrust fault below.

B. The duplex structures limited by clay filled slip planes are stretched out due to simple shear, and new steeply dipping slip planes intersect the older slip planes.

C. In the final phase the first generation slip planes are drag folded contemporaneous with the reorientation of the latest formed slip planes. 

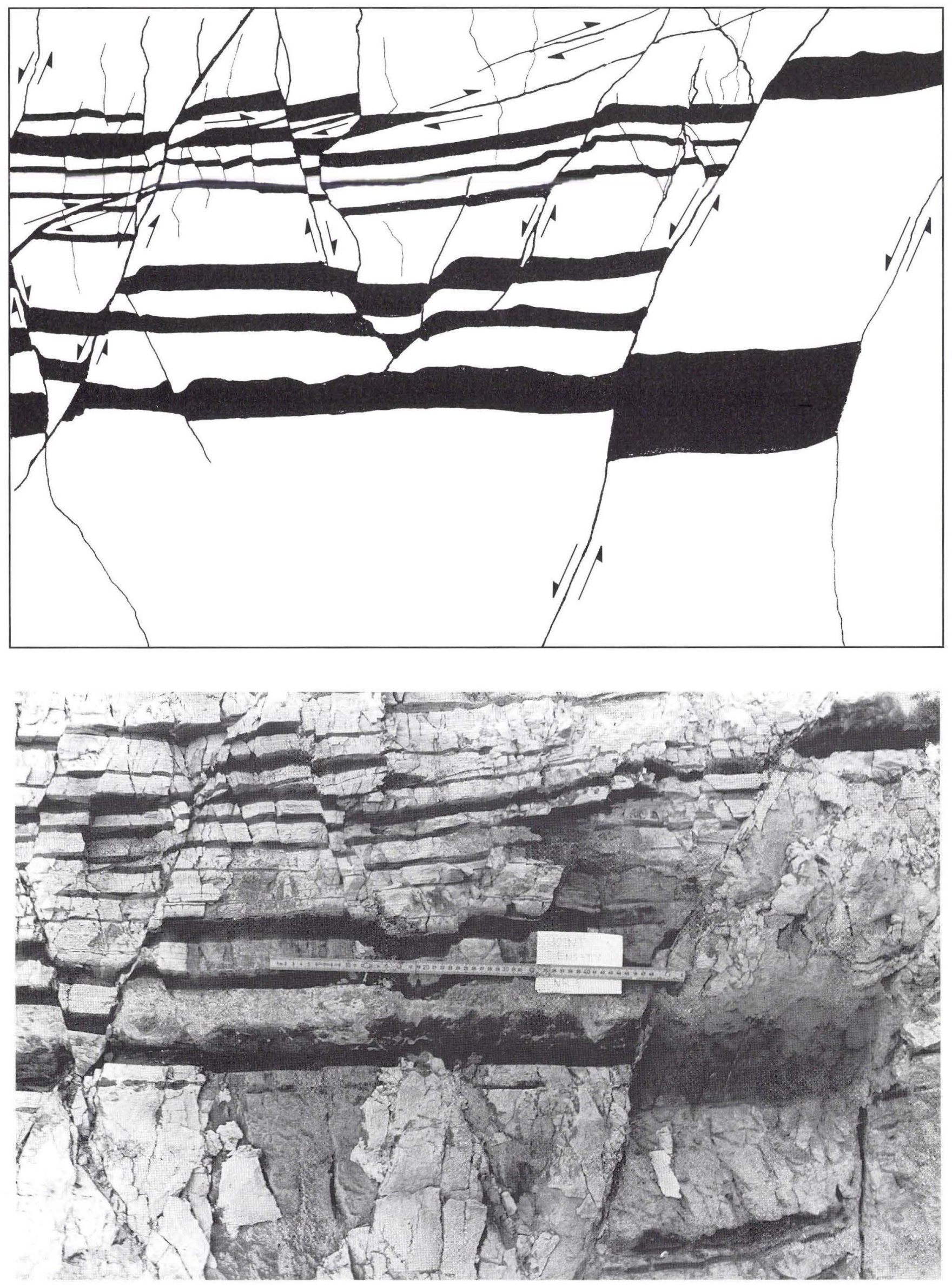

Fig. 11. Fault and joint pattern around ash layer +19 and +35 at $400 \mathrm{~m}$. Normal faults and extension joints cuts older reverse faults indicating compressive strain regimes overprinted by extensional strain regimes. The reverse faults are formed in the initial stage of compression. The normal faults are interpreted to have been formed during the passage over the foot-wall ramp. 
The fold was probably partly formed before the thrustmovement started, but it has been further folded by heterogenous simple shear deformation during the thrust phase, resulting in axial plane-parallel reverse faulting in the core of the recumbent anticlinal fold.

The diatomite above ash layer +118 consists of structureless diatomite with a few thin ash layers, and the very characteristic calcareous concretion horizon above ash layer +130 . The calcareous horizon appears to have acted as a very competent layer and forms almost isoclinal folds in the "nose" of the Hanklit Thrust Sheet.

From 400 to $420 \mathrm{~m}$ the diatomite between ash layer +1 and +35 is dominated by extensional steeply northward-dipping normal faults striking east-west (fig. 11).

These normal faults cut older low angle reverse faults, but at $380 \mathrm{~m}$ a reverse fault cuts a normal fault, indicating a compressional strain regime following an extensional regime.

The central part of the Hanklit Thrust Sheet (250- $380 \mathrm{~m})$ is almost horizontal in the upper part, and dips up to ca. $12^{\circ}$ to the NNE a few metres above the main thrust-fault. The upper part of the Fur Formation sediments are dominated by steep southward-dipping normal faults striking east-west. These normal faults cut older reverse faults.

The low-angle southward-dipping normal fault at $355 \mathrm{~m}$, cutting ash layer +101 , shows a clear example of compressional and extensional deformation along the same fault plane. The way the calcareous concretion horizon has been folded indicates reverse faulting, but a later phase of extension, has caused low-angle normal faulting along the same fault-plane.

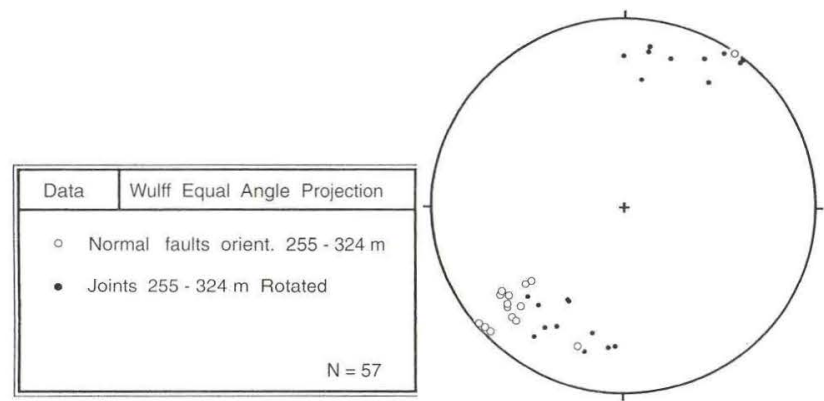

Fig. 12. Joint and fault orientations along the sole of the central part of the Hanklit Thrust Sheet. The normal faults have the same orientation as one set of the conjugating shear joints. The orientation of the joints and faults, after rotation of the sedimentary layers down to horisontal, shows that the joints were formed before the thrusting of the Hanklit Thrust Sheet.

As mentioned earlier, a number of normal faults display the diatomite just above the Hanklit Thrust Fault. These faults are abruptly cut by the thrust fault and no continuations are found in the Gullerup Thrust Sheet below. Analysis of the joint pattern in the same location as the faults showed a distinct set of conjugated joints. The joints are sub-vertical with the acute angle and corresponding Sub-vertical maximum compression directed SSE-NNW. The orientation of the normal faults matched the orientation of the SE-NW striking joints (fig. 12).

From the field evidence it is argued that these fault and fracture systems predate the glaciotectonic thrust faulting.

The rear part of the Hanklit Thrust Sheet (90-250 m) forms a monoclinal fold which strikes ca. $109^{\circ}$. The dip varies from almost horizontal in the uppermost southern part to $37^{\circ} \mathrm{NNE}$ at $180 \mathrm{~m}$. The Fur Formation sediments are however to some extent tectonically lengthened by normal faulting.

The monoclinal fold shows signs of at least two deformation phases: a compression phase with development of reverse faulting succeeded by an extensional phase characterized by normal faulting along low angle gently southward-dipping fault-planes and sub-vertical northward-dipping fault-planes.

\section{Joint patterns in the Fur Formation.}

A detailed examination of the joint patterns through the Fur Formation has been carried out between $150 \mathrm{~m}$ and $250 \mathrm{~m}$, where the monocline makes the stratigraphic column accessible (fig. 13).

In the lower part of the Fur Formation from ash layer - 17 to -13 which is dominated by laminated diatomite and few ash layers, the joint density is relatively low. The joint style is dominated by straight, parallel sets of shear-joints. Conjugated joint-set are rare, but a secondary joint-orientation can be recognized. Both joint sets cut the sedimentary stratification in a high angle $\left(>60^{\circ}\right)$ and have a rough, but planar joint surface (fig. $13 \mathrm{~A}$ ).

From ash layer -13 to +19 the diatomite are weakly-laminated-to-structure-less and characterized by moderate joint density. A system of reverse faulting indicates a lateral compressional strain regime. The diatomite are cut by a large number of small joints with a strongly curved pattern, which gives an impression of low intensity rupturing (fig. $13 \mathrm{~B})$. A dominant set of more or less parallel joints cut the stratification in a high angle $\left(>60^{\circ}\right)$.

The central part of the Fur Formation, from ash layer +19 to +118 , is dominated by numerous closely spaced ash layers interbedded with mainly structureless diatomite, and a few horizons with weakly-laminated to laminated diatomite (see fig. 11).

This part includes two well developed, very competent, horizons of calcareous concretions, which exerted a strong influence on the deformation pattern.

The moderate to intensive jointing related to this stratigraphic level is dominated by minor joints almost perpendicular to the stratigraphic layers. A secondary development of conjugate extension joints and conjugate shear fractures are clearly related to normal faulting and reverse faulting respectively.

The uppermost part of the Fur Formation consists of structureless diatomite with only a few thin ash layers. The diatomite is moderately to intensively fractured (fig. $13 \mathrm{C}$ ). There seems to be no preferred orientation of the joints, 
which are dominated by curved irregular jointplanes. Some of the planes have a plumose character which occasionally develops into tectonic brecciation.

The joint-intensity just below the transition to the Quaternary sediments is so great, that the overall impression in this part, is one of ductile deformation. In the frontal part of the Hanklit Thrust Sheet the jointing are so intense, that the deformation changes from brittle, in the lower part of the thrust sheet, to ductile in the frontal part.

\section{The Salgerhøj Thrust Sheet}

The Salgerhøj Thrust Sheet makes up the northernmost thrust sheet in the Hanklit Thrust Fault Complex (fig. 7).

The sheet consist of diatomite and ash layers of the Fur Formation overlain by glaciofluvial gravel and sand. The Palaeogene sequence includes the Fur Formation sediments from ash layer -13 to ash layer +101 . The top of the Fur Formation has been eroded, and compared to the Hanklit Thrust Sheet, more than five meters has been re-moved in the bottom of a glaciofluvial meltwater channel.

Only the frontal part of the Salgerhøj Thrust Sheet is exposed in the Hanklit cliff section. Here it constitutes the southern flank of a frontal overturned anticline fold.

The northern flank of the fold coinciding with the crest of the thrust sheet has been eroded by the sea, but part of the thrust sheet is exposed about $400 \mathrm{~m}$ further to the east along the coast.

Ash layers and calcareous concretions at the seafloor approx. $100 \mathrm{~m}$ off the coast toward north, mark the trend of the northern flank of the thrust sheet. The resistant beds strike approximately east-west and dip approximately $30^{\circ}$ towards north.

The frontal anticline of the Salgerhøj Thrust Sheet forms a hanging-wall anticline cut by a hanging-wall ramp and attached to the foot-wall flat on the back of the Hanklit Thrust Sheet (fig. 7).

The steeply dipping ash layers have an average strike of $89^{\circ}$. The structure continues at least $1000 \mathrm{~m}$ to the east, forming the edge of the steeply dipping slope facing the coast. The fold axis is almost horizontal with an east-west orientation.

The lowermost part of the glacigenic sequence is vertically orientated. On the boundary between the two lithological units slickenside lineations occur in bedding-parallel planes. The lineation has a vertical orientation and is interpreted as flexural slip displacement formed by folding of the frontal anticline during the thrusting of the Salgerhøj Thrust Sheet.

The uppermost part of the glacigenic sequence consists of fine-grained sand interbedded with glaciolacustrine clay and thin intercalations of diamictons. These beds are folded in a series of isoclinal folds with amplitude of about $1 \mathrm{~m}$ (see fig. 14). The fold axis is horizontal and orientated $100^{\circ}$, and the axial plane dips $45^{\circ} \mathrm{N}$.

The bedding of the medium to coarse grained meltwater sand in the main part of the glacigenic sequence is orientated perpendicular to the thrust and the bedding in the top of the Hanklit Thrust Sheet (point $100 \mathrm{~m}$ in the cross section, fig. 2) thus illustrating the hanging-wall ramp footwall flat relationship. 


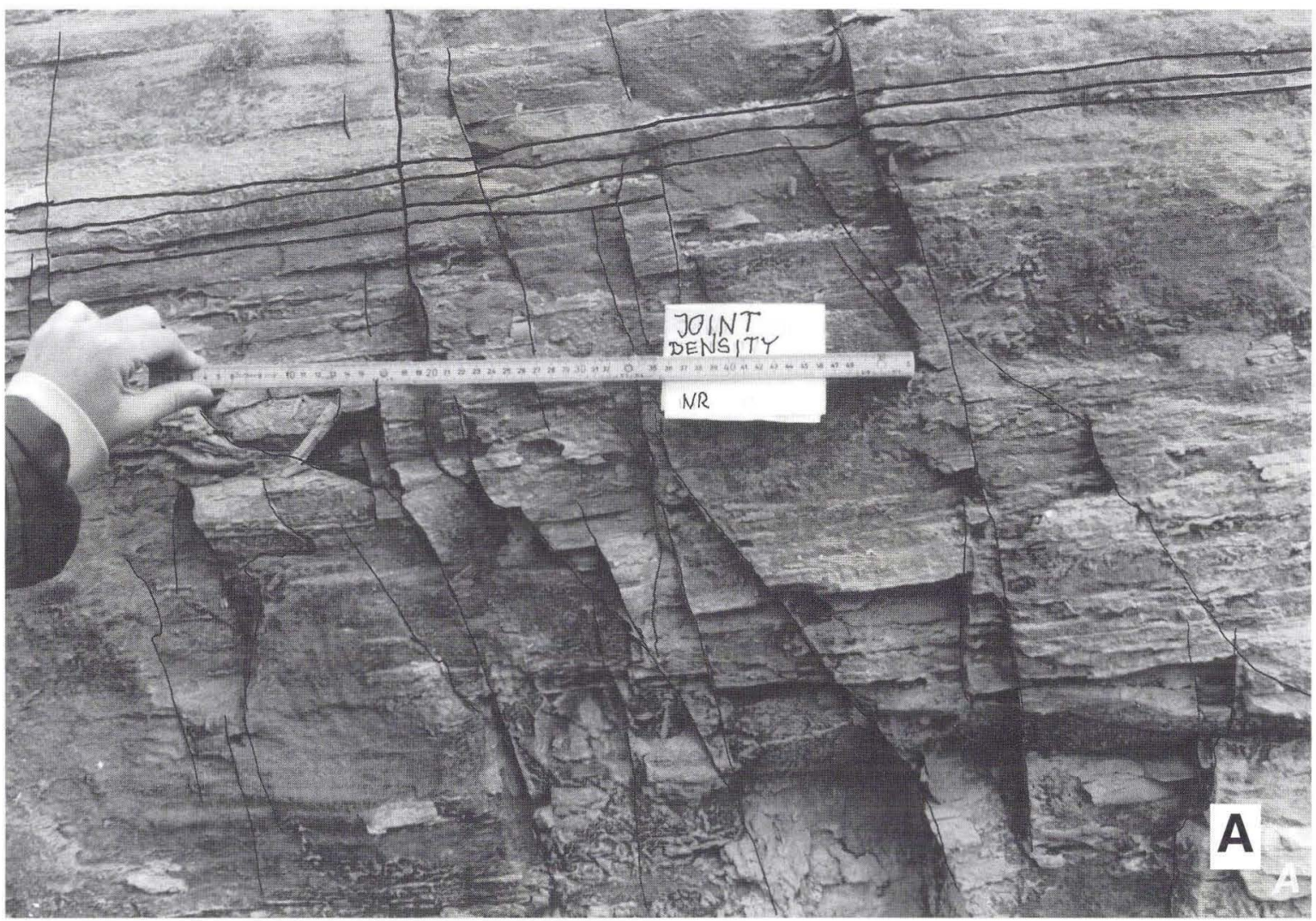

Fig. 13. Joint-pattern in the diatomite.

A. joint-pattern in laminated diatomite. Notice the relatively weak density and the straight planar conjugating joints cutting the stratigraphical bedding at a steep angle.

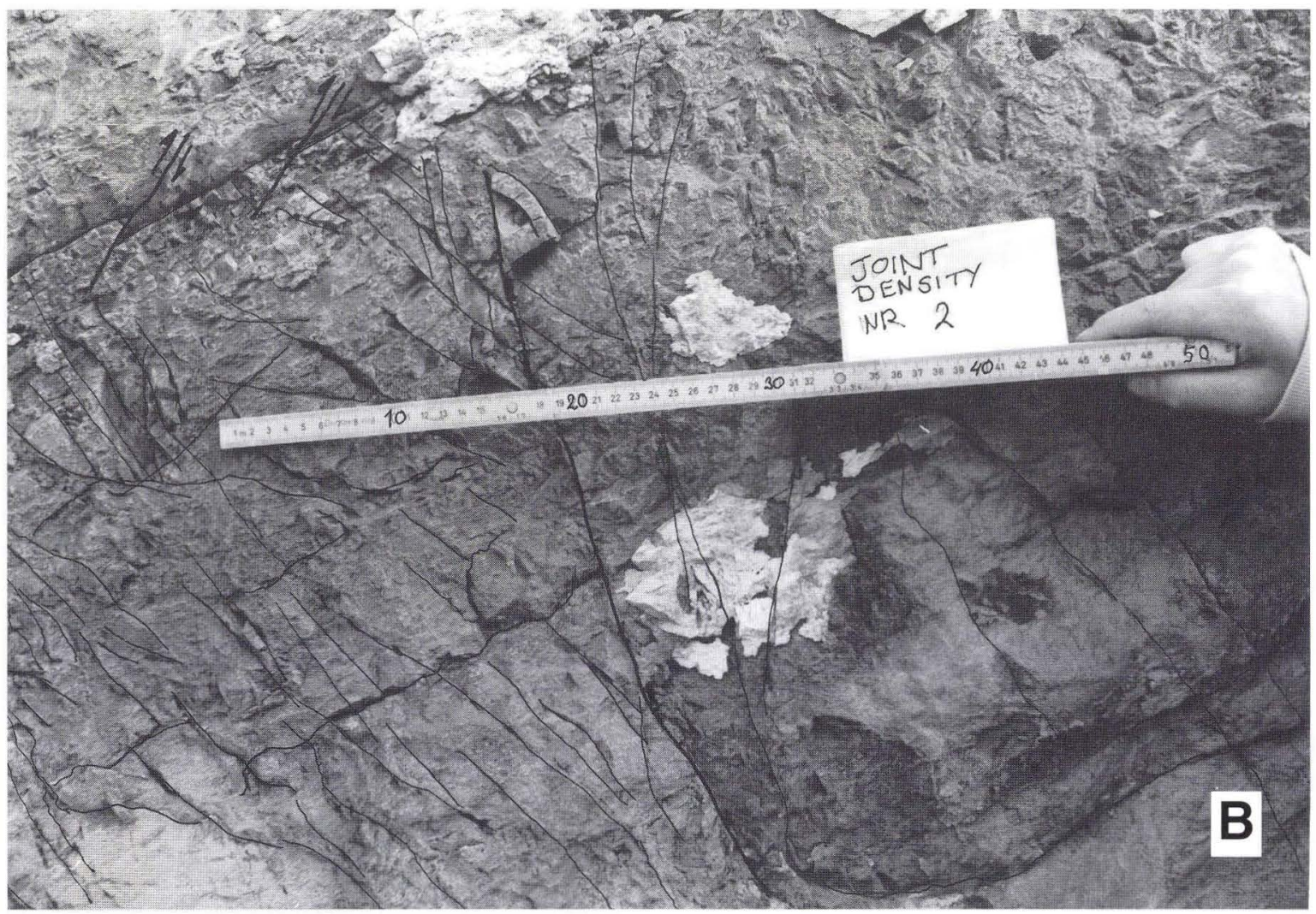

Fig. 13. Joint-pattern in the diatomite.

B. Jointing in weak laminated diatomite. The density is moderate with more irregular curved jointing than in A. Notice the reverse faulting in the upper left corner of the figure. 


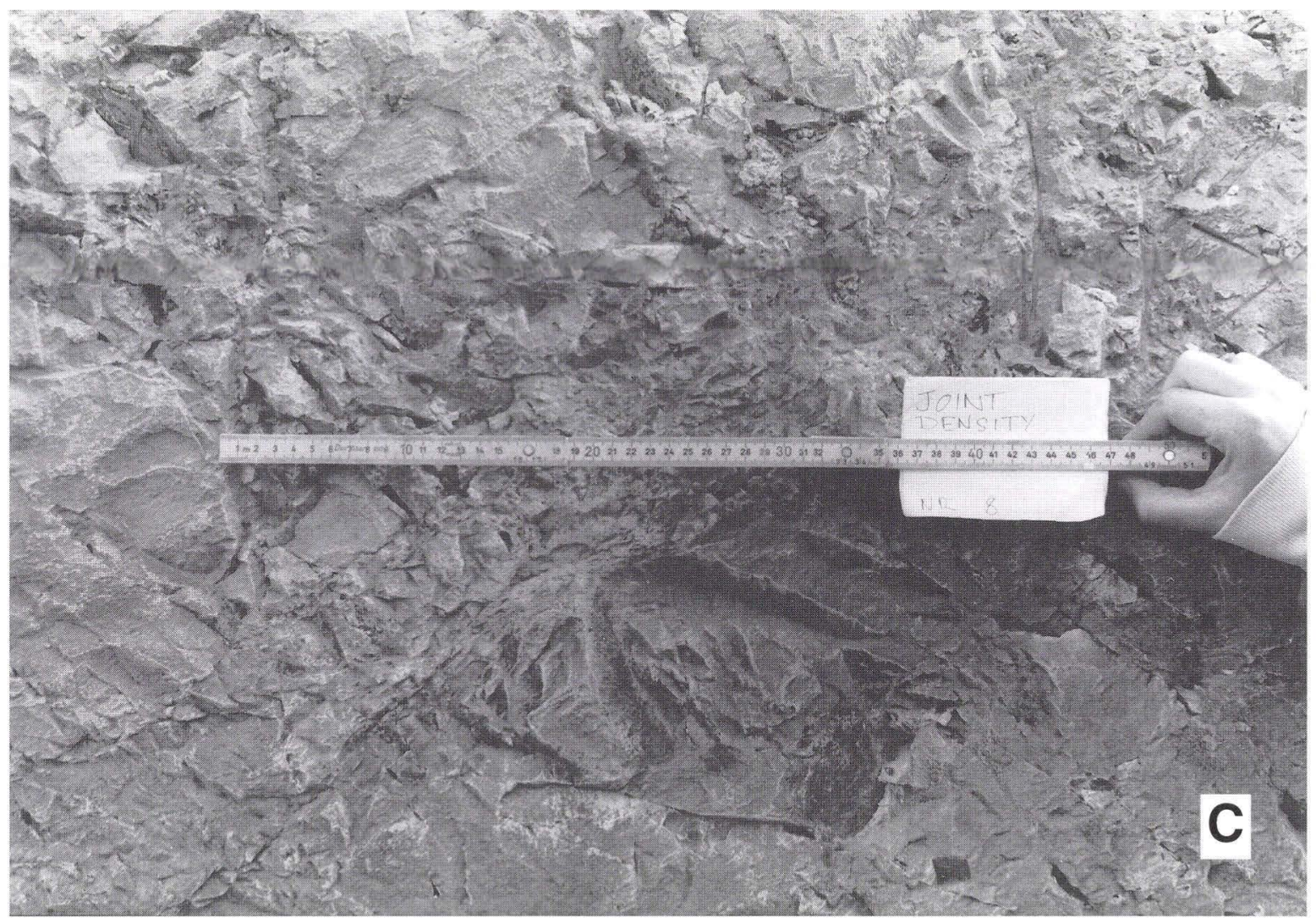

Fig. 13. Joint-pattern in the diatomite

C. Jointing in structureless diatomite. Irregular jointing along strongly curved planes, often with a plumose character dominates. The density of the jointing changes from moderate to great in the uppermost part of the Fur Formation.

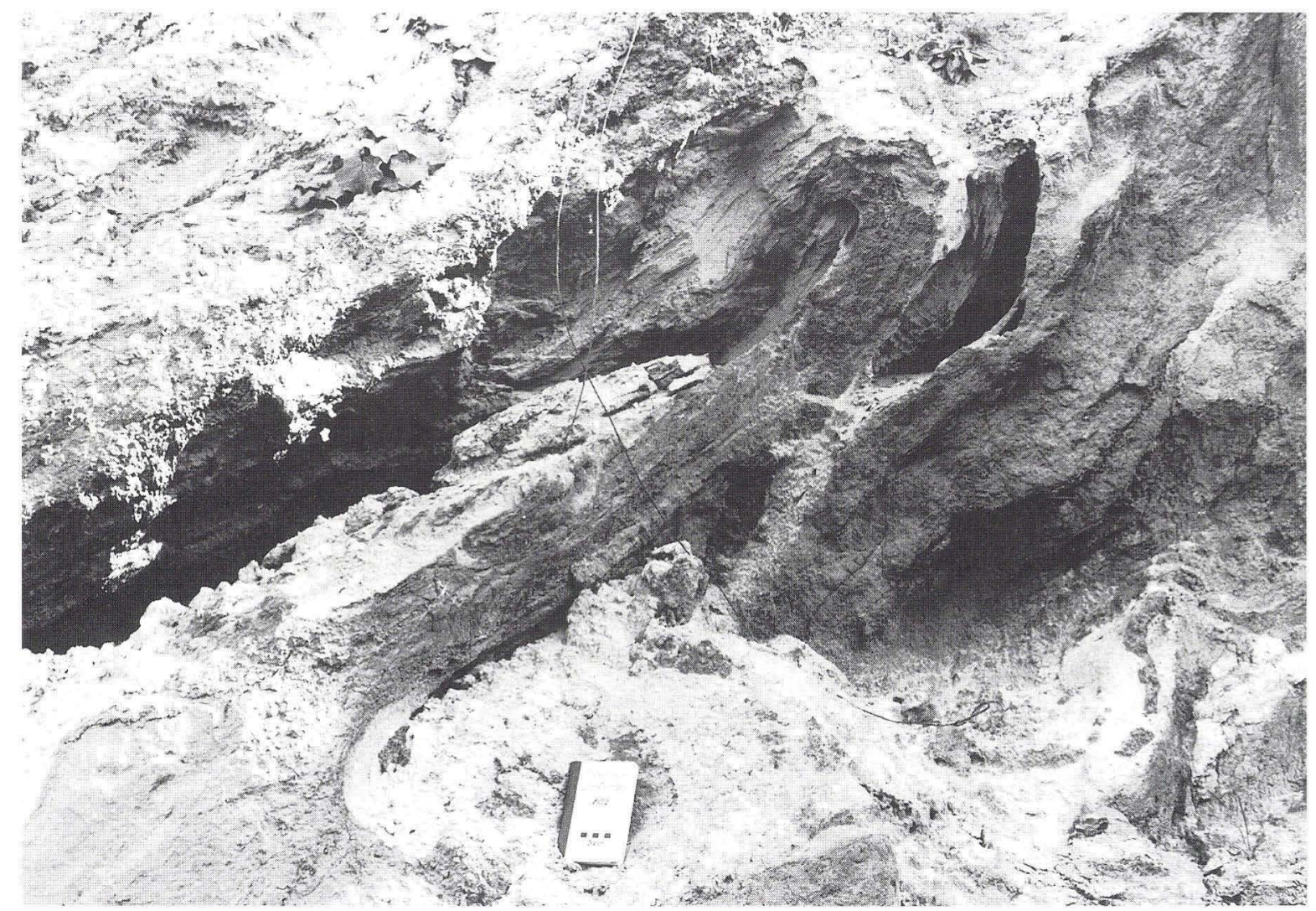

Fig 14. Isoclinal folds in the glaciolacustrine beds on the southern flank of the frontal anticline in the Salgerhøj Thrust Sheet at location $110 \mathrm{~m}$ (fig. 2). 


\section{Balanced cross-section}

In order to understand the development of the type of glaciodynamic deformation outlined above, it is very important that the structural cross section is valid, and that the structure can be "restored" to the state before deformation.

The well defined layer thickness in the Fur Formation facilitated the construction of a palinspastic section.

The principles of the construction of balanced cross-sections follow the model described by Dahlström (1969) and Hossack (1979).

In glaciotectonic studies the method has been successfully applied by Croot (1987a, 1988) for unravelling the structural complexity and dynamic development of thin-skinned glaciotectonics.

\section{Conditions for the use of a balanced cross-section}

Hossack (1979) established the following conditions for using balanced cross-sections:

1. Plane strain deformation. $\lambda_{2}=1$. and $\lambda_{1}>\lambda_{2}>\lambda_{3}$.

2. Well defined décollement plane.

3. Well defined pre-deformational layer thickness.

4. The deformation takes place along well defined thrust planes.

1. The general deformation for the Hanklit Thrust Fault Complex is plain strain, as shown by the development of uni-directional reverse faulting and imbricated thrusting.

The frontal part of the thrust sheet has been affected by simple shear deformation.

2. The sole of the Hanklit Thrust Sheet is well defined ca. $35 \mathrm{~cm}$ below ash layer -17 . This level constitutes the décollement plane. Décollement planes are typically developed at a lithological change in the layers, often in a highly porous impermeable sediment. The well laminated diatomite, which is a highly porous and impermeable, changes below ash layer -17 to a darker, clayey, weakly-laminated diatomite.

One to two metres below this level, a dark silicified claystone are known from other localities on Mors (Pedersen \& Surlyk, 1983), and it is probably present at Hanklit too.

3. The pre-deformational layer thickness of the Fur Formation sediments are extremely well defined, allthoug the Quaternary sediments vary to some extent.
4. The Hanklit Thrust is well-defined at the intersection between the Hanklit Thrust Sheet and the Gullerup Thrust Sheet.

The foot-wall flat of the Gullerup Thrust Sheet is well defined by the location of the clayey till, and the foot-wall ramp are likewise well defined by the termination of the till (fig. 15). The hanging wall-flat of the Hanklit Thrust is well defined by the sheared diatomite just below ash layer 17 , and the hanging-wall ramp is obviously seen cutting up the stratigraphical section.

The blind thrust below the Gullerup Thrust Sheet (fig. 15) is questionable, but the geomorphology of the area east of Hanklit suggests that the elongated hill, south of the pushridge consisting the Hanklit Thrust Sheet, is in fact a thrust sheet, or an anticlinal fold parallel to the Hanklit Thrust sheet.

The Salgerhøj Thrust is well defined as a hanging wall ramp cutting the densely packed ash layers in the upper part of the Fur Formation. It continues across the unconformity between the Fur Formation and the glacigenic sediments up into the meltwater deposits. The footwall flat is outlined by the glaciolacustrine clay beds in the top of the Hanklit Thrust Sheet.

\section{Assumptions}

A cross-section perpendicular to the major structures was constructed (fig. 15), and a construction of the poorly exposed and the eroded parts of the cross-section was interpreted from the following assumptions:

1. The Gullerup Thrust Sheet has a constant layer thickness of the Fur Formation sediments of $29 \mathrm{~m}$ from ash layer -17 to ash layer +101 .

2. The unfolding of the Hanklit Thrust Sheet's frontal part outlines the geometry of the hanging-wall ramp and approximately $100 \mathrm{~m}$ of the hanging-wall flat.

This part of the Hanklit Thrust Sheet coinsides with the foot-wall ramp and approximately $100 \mathrm{~m}$ of the décollement surface. The structural geometry of the paired footwall - hanging-wall relationship, thus enables a construction of the Hanklit Thrust Fault below sea level.

3. The calcareous concretion horizon at ash layer +101 at the sea floor north of Hanklit is interpreted to be the northern flank of the anticline fold which forms the frontal part of the Salgerhøj Thrust Sheet. 
4. The Quaternary sediments vary in layer thickness, however the average thickness in the Gullerup Thrust Sheet is estimated to be $28 \mathrm{~m}$.

5. The layer thickness of the Hanklit Thrust Sheet is regded to be the same below sea level as above sea level.
In the interpretation of the subsurface structures we aimed to give the simplest reconstruction that can be envisaged from the exposures. The exact depth to the predicted décollement surface is unknown due to lack of evidences. Meanwhile it is unlikely to be situated deeper than $100 \mathrm{~m}$ below sea level according to the geological profile accross Thisted Bredning from Thy to Central Mors (Pedersen, 1989a).

N

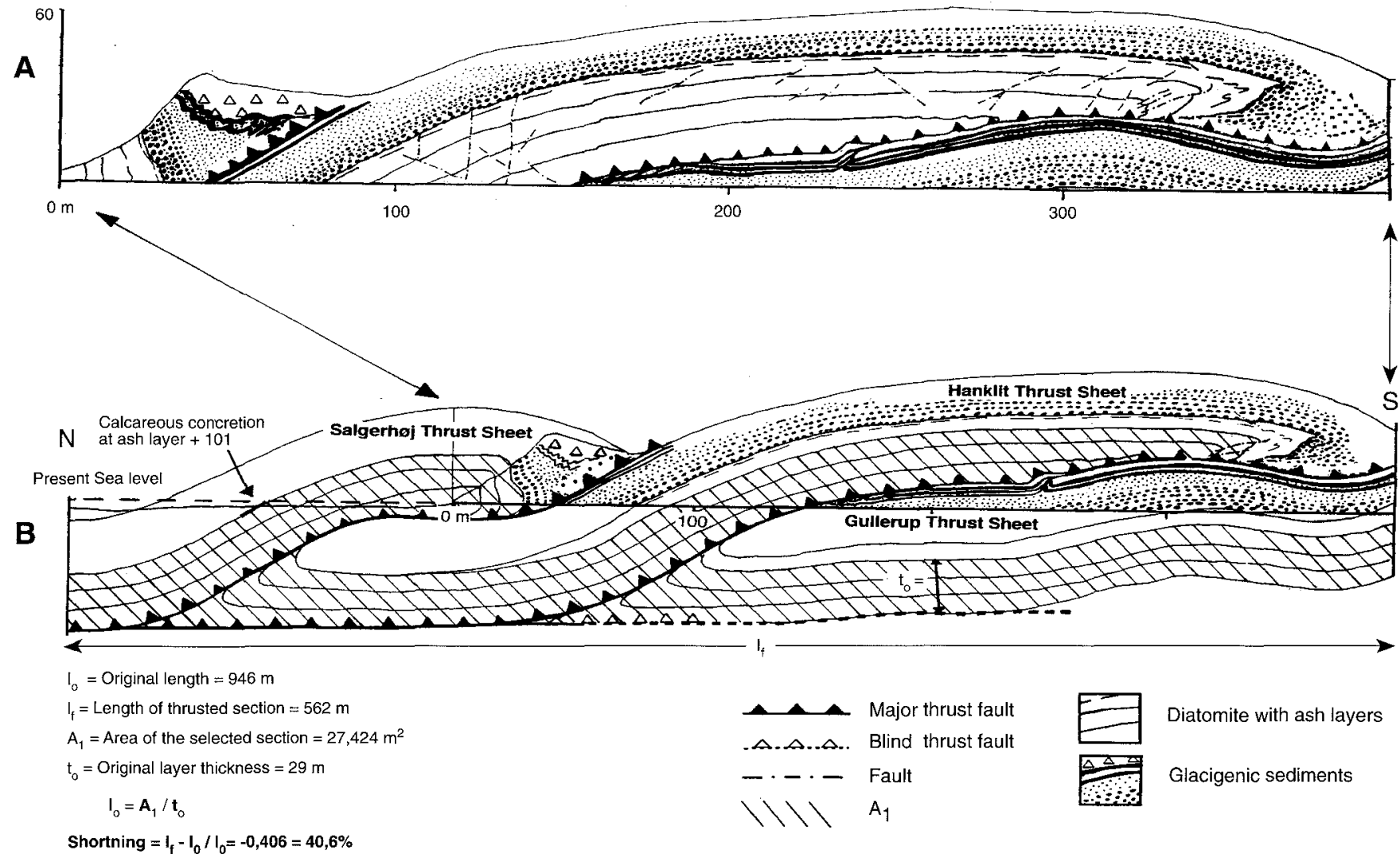

Fig. 15.

A: Geological cross-section of the Hanklit Thrust Fault Complex constructed perpendicular to the fold-axes.

B: Interpretation of the thrust fault architecture in the subsurface below the Hanklit Thrust Fault.

Note the blind thrust below the Gullerup Thrust Sheet and the cross-hatched area applied for the areal balancing.

\section{Area balancing}

Due to the variation in the thickness of the Quaternary sediments and the fact that some of the sediments were eroded, a total area balancing is not possible. However area balancing can be carried out on a restricted area between ash layer -17 to +101 . This stratigraphical section is well defined throughout the cross-section and is documented to have a constant thickness.

The calculation of the area $\left(A_{1}\right)$ between ash layer -17 and +101 was carried out as demonstrated in Fig. 15. The sedimentary layer thickness $\left(\mathbf{t}_{0}\right)$ of the diatomite between ash layer -17 and +101 is known to be $29 \mathrm{~m}$, and the pre-deformational horizontal extension of the section $\left(l_{0}\right)$ is calculated from the equation:

$$
1_{0}=A_{1} / t_{0}
$$

The extension e of the compressive deformation of the section is calculated from the equation:

$$
\mathrm{e}=\left(\mathrm{l}_{\mathrm{f}}-\mathrm{l}_{0} / \mathrm{l}_{0}\right)
$$

$1_{\mathrm{f}}=$ the length of the cross-section after the thrusting.

$$
\underline{e}=(562-946) / 946=-0,406
$$

Total shortening of the Hanklit Thrust Fault Complex in the compressive part is approximately $\underline{40 \%}$ 


\section{The 3-dimensional framework of the Hanklit Thrust Fault Complex}

For the construction of the 3-dimensional framework of the Hanklit Thrust Fault Complex a geoelectrical investigation of the extent of the Hanklit Thrust Sheet was carried out (Jensen \& Pedersen, 1989).

A grid covering an area of about $1000 \mathrm{~m} \times 150 \mathrm{~m}$ to the east of the Hanklit cliff section was constructed and 13 geoelectric soundings were measured with Schlumberger configuration.

Geoelectrical measurements of strongly folded or dislocated sediments are normally extremely complicated, but as the central part of the Hanklit Thrust Sheet is almost horizontal and well defined it was believed to be possible to measure the distance from the ground surface down to the diatomite and to some extent down to the lithological contrast between the diatomite above the thrust fault and the gravel and sand meltwater deposits below.

The soundings were interpreted and correlated to each other and constitute the basis for the construction of the block diagram (fig. 16). The geoelectric investigation indicates that The Hanklit Thrust Sheet continues almost unchanged for more than $1 \mathrm{~km}$ to the east. Unfortunately extensive landsliding prevented further investigation of the continuation of the thrust sheet.

Due to the geoelectric investigation it was furthermore demonstrated that the fold axis of the frontal anticline of the Hanklit Thrust Sheet has a variable orientation with a depression around $100-200 \mathrm{~m}$, and a culmination at about $600-700 \mathrm{~m}$ measured along the baseline from the edge of the cliff. A consequence of this culmination is that the Hanklit Thrust Sheet in the eastern part of Flade Klit is situated ca. $20 \mathrm{~m}$ higher above sea level than at the cliff section. The cover of coarse glacio-fluvial sediments are thinning towards the east and at approx. $320 \mathrm{~m}$ from the cliff, the diatomite is exposed at the surface of the hillcrest. In the eastern-most part a clayey till covers the area. This till may either be the uppermost till in the glacigene sequence or may indicate a discordantly deposited till above the thrust complex.

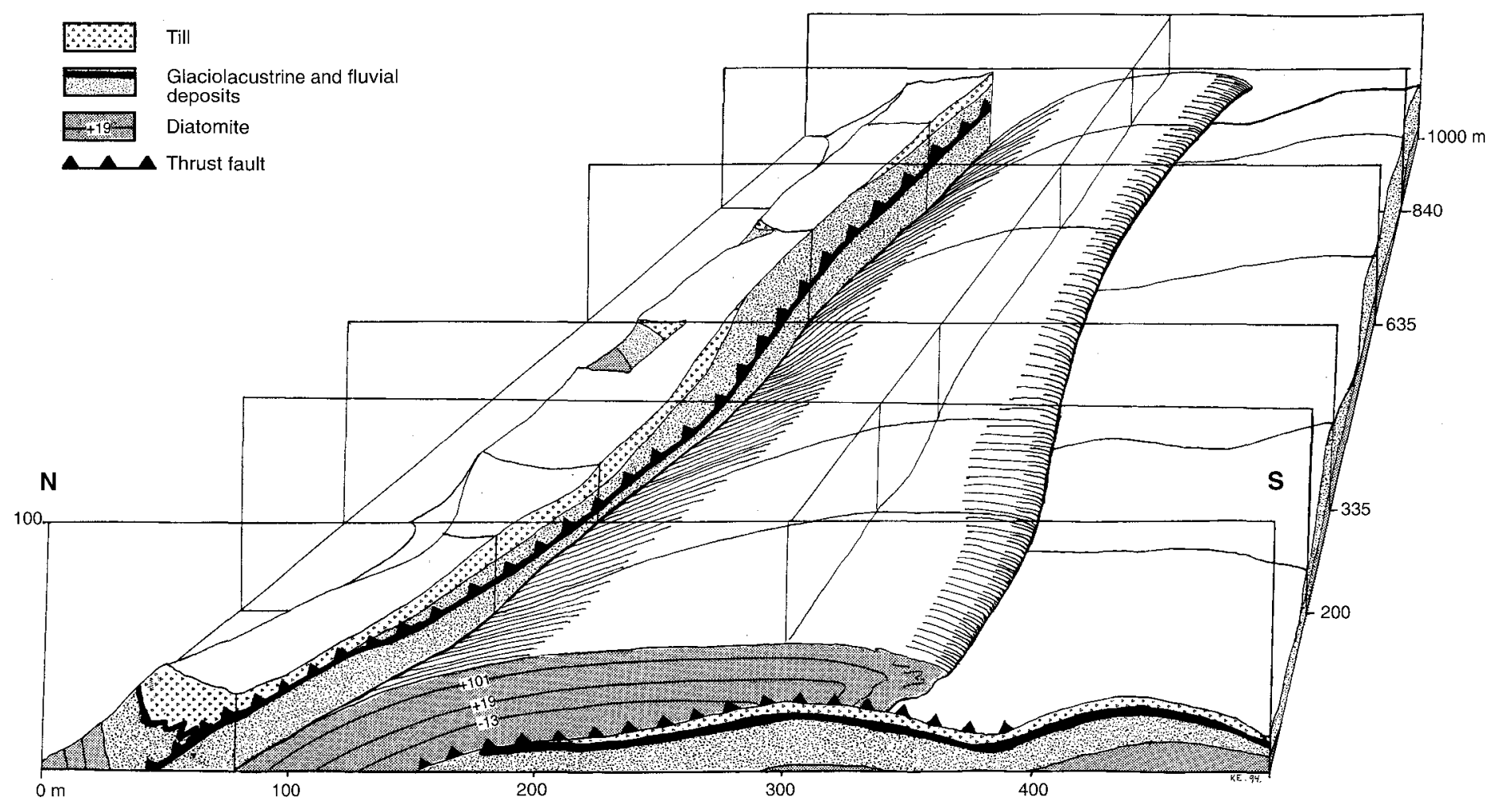

Fig. 16. Three-dimesional framework of the Hanklit Thrust Fault Complex based on geoelectrical soundings (Jensen \& Pedersen 1989). 


\section{The structural development of the Hanklit Thrust Fault Complex.}

Based on the balanced cross-section the structural development of the glaciotectonic deformation is illustrated in four stages (fig. 17). A number of deformation features are related to the individual stages and are successively overprinted by structures related to the subsequent stages. One set of structural features pre-dates the glaciotectonic structures and is described individually in the following section.

\section{Deformation stages.}

Stage 1: In the sediments beneath and in front of an advancing glacier stress builds up and creates the initial fracturing. Reverse faults and shear-joints develops simultaneously with the initiation of the folding of the sediments.

The main décollement surface occurs in the diatomite ca. $35 \mathrm{~cm}$ beneath ash layer -17 , and listric thrust-faults are generated from this décollement-plane and cut up through the stratigraphical section.

Stage 2: In the succeeding stage the Salgerhøj Thrust Sheet is thrusted along the Salgerhøj Thrust onto the foreland. The frontal part of the thrust sheet is folded into an overturned anticlinal fold.

As the thrusting of the Salgerhøj Thrust Sheet ceases, the stress is transmitted into the underlying and frontal sediments enlarged by the weight from the Salgerhøj Thrust Sheet.

Due to the lateral compression, reverse faulting and conjugate jointing are formed with the maximum stress in an almost horizontal north-south direction.

The décollement-plane is still located just beneath ash layer $\mathbf{- 1 7}$, and thrusting along the Hanklit Thrust Fault propagates upwards along the footwall ramp.

A good example of the reverse faults related to this initial deformation is seen displacing the ash layers below and above ash layer +101 at $250 \mathrm{~m}$ and $325 \mathrm{~m}$ in fig. 2 .

Stage 3: In stage 3 the main thrusting along the Hanklit Thrust Fault takes place.

Twisting of the thrust sheet during passage of the footwall ramp appears, resulting in a slight reorientation of the bedding. A set of vertical and low-angle southward dipping normal faults are formed above the bend of the Hanklit Thrust Fault (the intersection between the footwall ramp and flat). These normal faults are laterally transported into the present position in the frontal part of the Hanklit Thrust
Sheet and appear at $400 \mathrm{~m}$ in the cross section (fig. 2).

During the thrusting the uppermost sediments of the Gullerup Thrust Sheet are deformed and soft sedimentar structures related to over-saturated sediments are formed. The thrust plane develops into a thrust zone including water escape structures, dragfolding and parasitic secondary shearzones (fig. 9 and 10).

Stage 4: In the final phase of the thrusting the frontal part of the Hanklit Thrust Sheet is folded into a recumbent, overturned anticlinal fold. In the core of this fold a set of reverse faults parallel to the axial plane are developed and the calcareous concretion horizon at ash layer +130 is inhomogeneously folded.

Reverse faulting and jointing in the central and frontal part of the thrust sheet superimpose the former fault features. In the rear part of the Hanklit Thrust Sheet normal faults are generated above the ramp. Note that these faults are not superimposed by the late reverse faulting in contrast to the former normal faults generated in stage 3 .

Along the footwall flat the satellite thrusting of the till creates the "duplex structure" at $350 \mathrm{~m}$ (fig. 2 and 8 ).

In the final phase of stage 4 folding of the Gullerup Thrust Sheet appears probably above a blind thrust fading towards the south.

The stages described above is included in one glaciotectonic unit related to a single glaciodynamic event according to the definition of Pedersen (1993) (see later).

\section{Pre-glaciotectonic deformation}

Along the sole of the Hanklit Thrust Sheet a set of anomalous normal faults occur (fig. 18). The displacements range from $10 \mathrm{~cm}$ to about $1 \mathrm{~m}$ with down thrown blocks to the north. The faults are extensional faults with a typical fanning framework of syn- and antithetic smaller faults developed in the hanging wall block. Minor roll-over anticlines are often developed in relation to these frameworks (fig. 18). The strike of the faults are NW-SE, thus forming an oblique angle to the main axis of thrust fault deformation. Planar conjugating shear-joints with maximum strain $\left(l_{1}\right)$ in an almost NE-SW horizontal direction and minimum strain $\left(l_{3}\right)$ in a horizontal NW-SE direction are related to this extensional deformation. 
In the steeply dipping southern limb of the frontal anticline in the Salgerh $\phi j$ Thrust Sheet a set of horizontal faults appear (at 50-60 $\mathrm{m}$ in the profile fig. 2). They are listric, curving upwards in the down section direction and are regarded to be reorientated normal, extensional listric faults related to the same extensional deformation. These faults are postdated by the erosional unconformity to the glacigene sediments, thus indicating that this extensional deformation only affected the Tertiary lithological units.
The interpretation of the early extensional deformation phase is therefore that the faults were formed due to adjustments of the late Tertiary basin where subsidence occured between the elevated Thisted dome to the north and the Erslev diapir to the south (see fig. 3). This extensional faulting may have created the initial ramp and flat fractures which were inherited by the glaciotectonic deforma-tion.

100

1
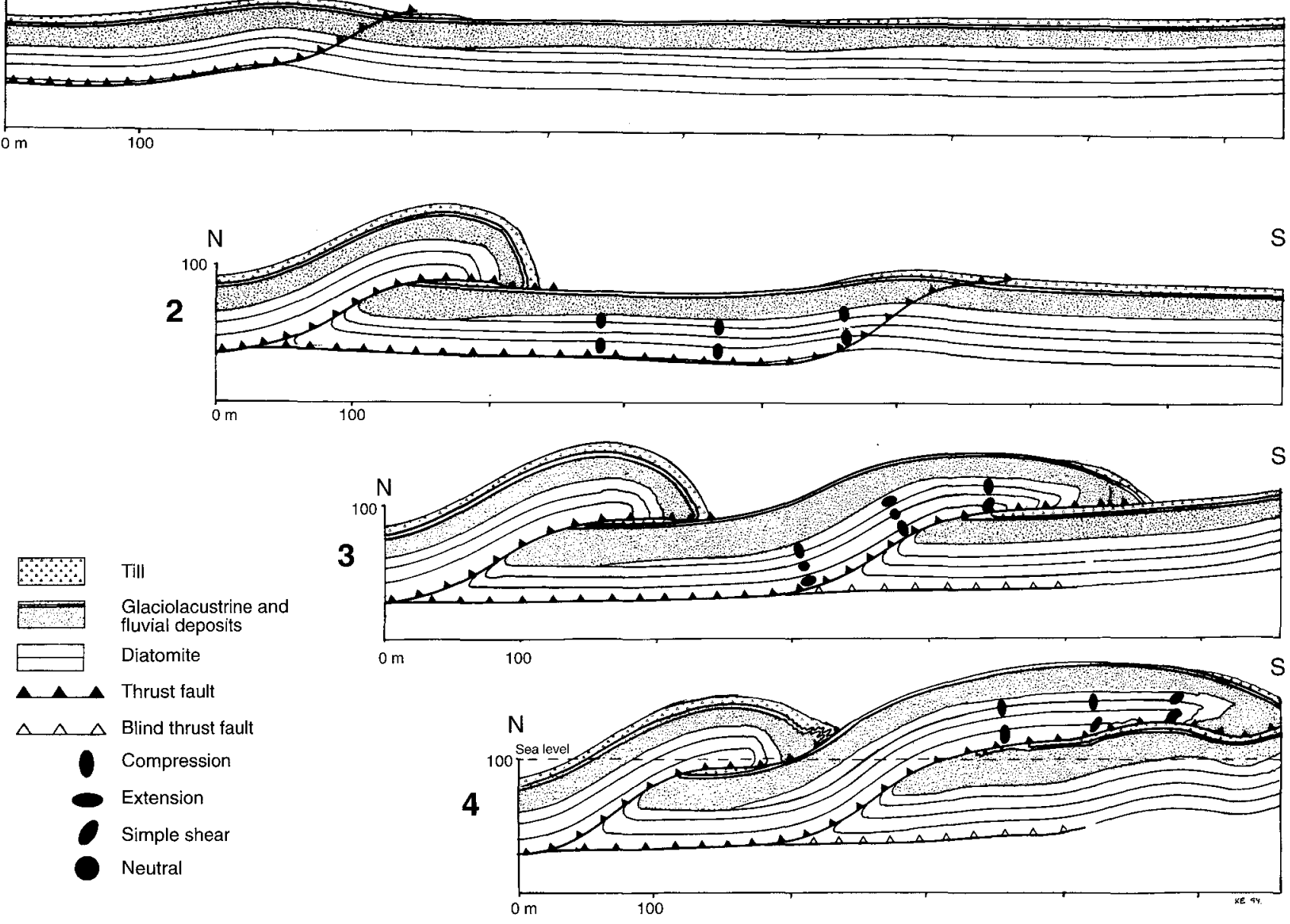

Fig. 17. Four steps illustrating the development of the Hanklit Thrust Fault Complex based on the balanced cross section. The changes in strain regimes during the thrusting are illustrated with strain ellipsoids. 

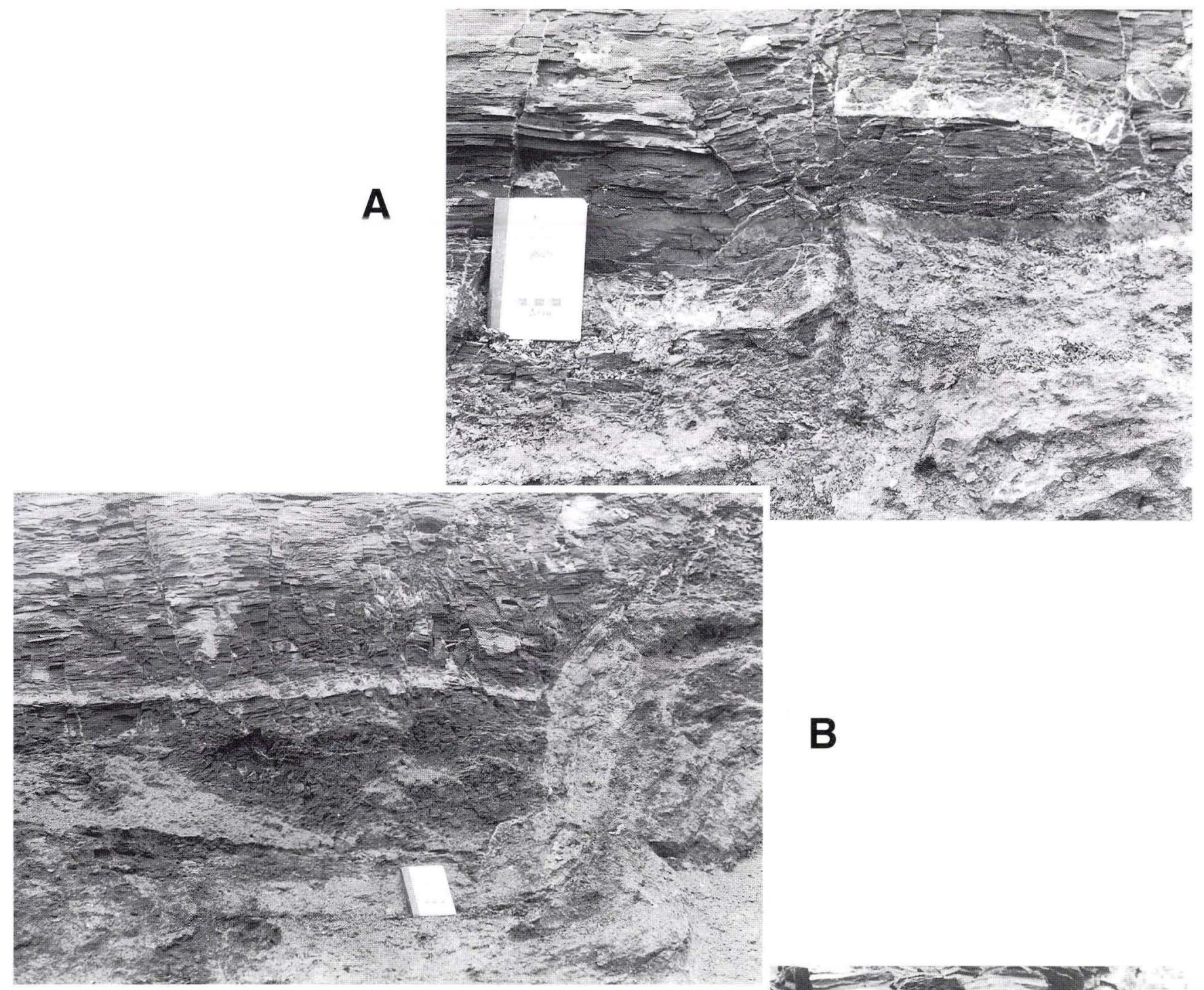

B

Fig. 18. Normal faults at the sole of the Hanklit Thrust Sheet, notice that the faults are truncated by the thrust fault.

A. Detail of normal fault with dark laminated diatomite in the upper part and light brecciated glacigenic sediments in the lower part of the photo. The displacement is about $30 \mathrm{~cm}$. Note the monocline flexure along the down thrown side of the fanning satelite faults which cross cut the monocline.

B. Normal fault displacing the diatomite (dark) with the marker ash layer-17 (thin light band). The displacement is nearly $1 \mathrm{~m}$, and the normal fault is truncated by the thrust fault near the position of the notebook.

C. Detail of normal fault with a fault splay cross cutting a roll over anticline which bends the laminated diatomite. Light, $4 \mathrm{~cm}$ thick layer above the notebook is ash layer -17 .

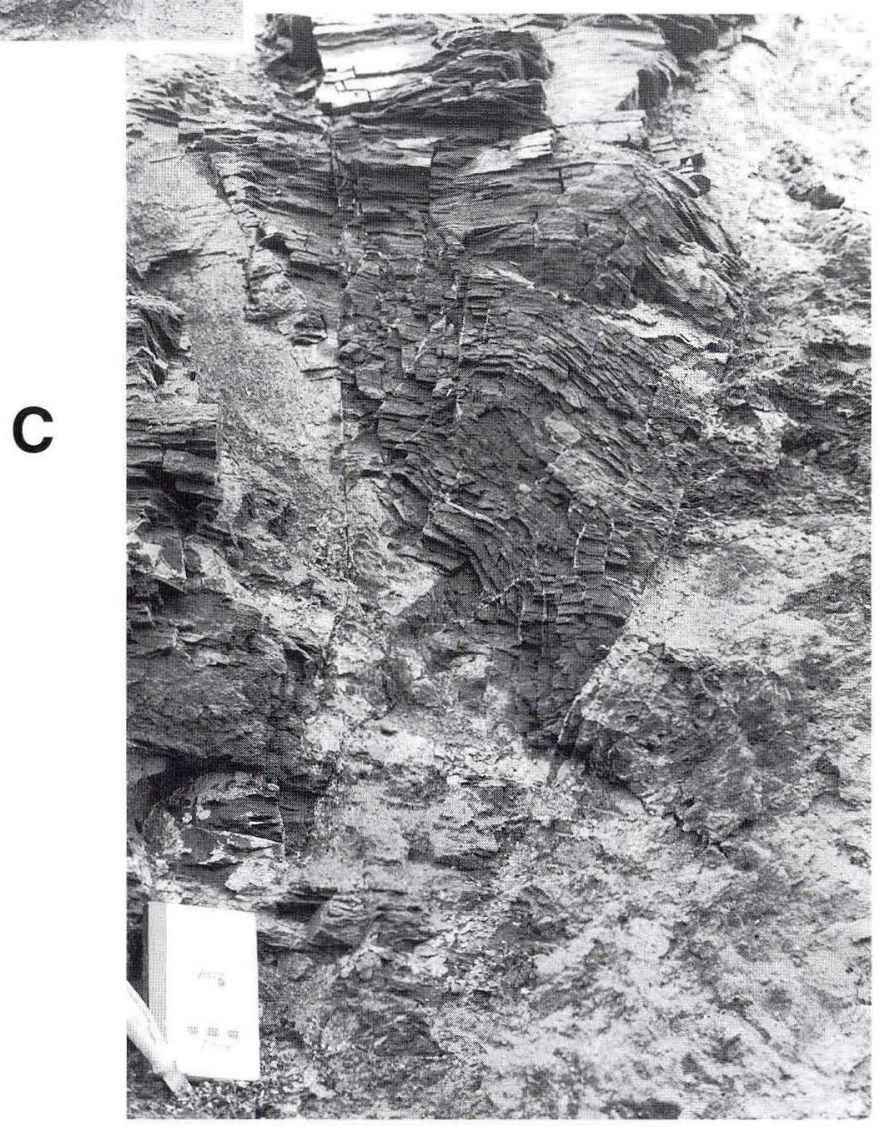




\section{Discussion}

This discussion is focused on two subjects: the division of the Hanklit complex into glaciodynamic sequences and the integration of the related glaciodynamic events within the glacial stratigraphy of western and northern Denmark. The concepts of "glaciodynamic sequence" and "glaciodynamic event" are used as defined by Pedersen (1993) (fig. 19).

The important differentation in this concept is that the glaciotectonic unit, as for example represented by the Hanklit thrust faulting, may represent one glaciodynamic sequence. This concept is an expansion of ideas formulated by Berthelsen (1978). Furthermore the glaciotectonic unit comprices all structures related to a single event of deformation. This deformation may even be seperated into succesive deformation phases.
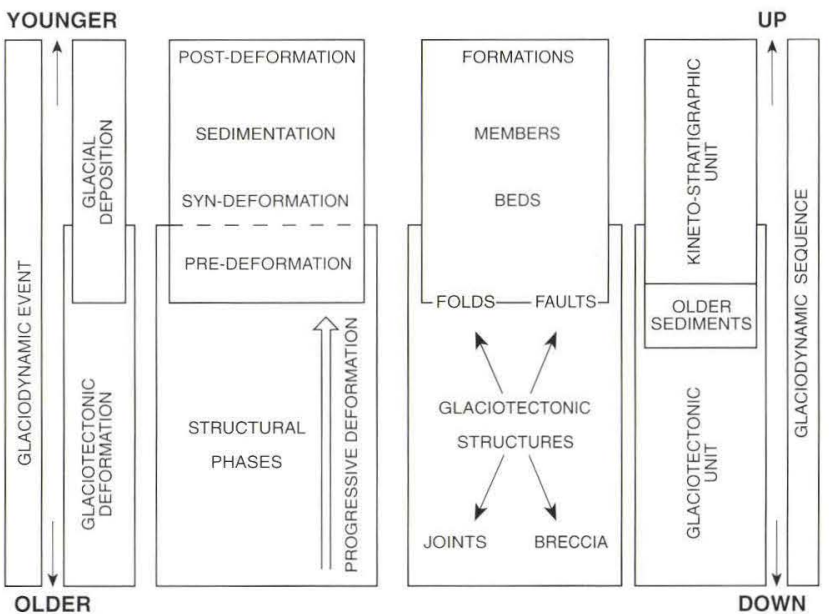

Fig. 19. A schematic presentation of the terms used in the analysis of glaciodynamic sequenses (Pedersen, 1993).

The observed glaciotectonic structures form the basis of the glaciotectonic unit. These are interpreted as structural phases (one or several) within a glaciotectonic deformation.

The lithostratigraphic units, which are genetically related to the glaciotectonic unit are termed the kineto-stratigraphic unit. The kineto-stratigraphic unit comprises at least one till and often also glaciofluvial, glaciolacustrine or glaciomarine deposits. The oldest part of a kineto-stratigraphic unit, eventually together with older sediments, may contain glaciotectonic structures, whereas the younger part of the kineto-stratigraphic unit represents postdeformation sedimentation. The analysis of glaciodynamic sequenses leads to the recognition of glaciodynamic events. Each of these represents a regional advance of an ice cap.

\section{Glaciodynamic sequences}

\section{Three glaciodynamic sequences are recognized:}

1. The first sequence comprises the glaciofluvial unit deposited on the unconformity above the pre-Quaternary Fur Formation. This glaciofluvial to -lacustrine unit is interpreted as having been formed during the melting of an ice cap, probably related to an advance from the north or northeast, based on the clast-composition and the palaeo-current directions.

The interpretation of the unit as representing only the retreating part of a glaciodynamic event is based on the change in depositional environment from high-energy braided stream to low-energy lacustrine environment.

2. The second sequence consists of the overlying till which is interpreted to be a lodgement till deposited by an ice advance probably from the north (Hundahl, 1988).

At Hanklit the till is the only preserved indication of the second glaciodynamic event.

3. The third glaciodynamic sequence is only represented by the glaciotectonic unit, which includes the sequential thrust fault deformation. This third event includes an ice advance from the north.

The lack of deposits from the last ice advance and the nature of the deformations at Hanklit favours a fast moving glacier, with a steep front, thus indicating a kind of "surgetype glacier".

Glacier surges are a well known phenomenon from recent glaciers (Clark \& Blake, 1991; Croot, 1988b; Meier \& Post, 1969), and even though little is known from surges in "low-land glaciers", they might have taken place during glacial times.

Besides that, the sediments at Hanklit were not permafrozen during the thrusting, as shown by the soft sediment structures and the internal deformation pattern in the thrust sheets.

One might expect the surface to be permafrozen during a major glacier advance, but a short readvance (local glacier surge) during a general ice regression would probably transgress thawed sediments.

The possibility of a major glacier advance towards the Main Stationary Line, triggered by a major "ice cap collap$\mathrm{se}^{\mathrm{N}}$ at the end of the Weichelian, followed by a regional meltdown of the glacier, is however still a feasible theory (regional glacier surge), as such a glacier advance might be expected to transgress thawed sediments too. 


\section{Glacial Stratigraphy}

It has been proposed that two major ice advances occurred in the late Weichselian: the Norwegian advance, and the Main advance from NE towards the Main Stationary Line (Houmark-Nielsen, 1987; Berthelsen, 1978), but Kronborg (pers. communication, 1994) suggests an early Weichselian ice advance from Norway approx. 70.000 BP. An early Weichselian advance has also been proposed by NoeNygaard (1992) and Petersen \& Kronborg (1990).

Pedersen et al. (1988) suggests that the Late Weichslian Norwegian ice advance gradually shifted ice movement direction from north to north-east and becomes part of the main advance from north-east.

No Eemian sediments are preserved at Hanklit, either they were all eroded away, suggesting that the strata are all Weichselian, or they were never deposited, perhaps because the landscape was above sealevel during the Eem.

Two models for the glacial stratigraphy at Hanklit are proposed which fit such hypotheses. Due to the lack of dating both models represent possible correlations .

Model 1: The first model advocates three glaciodynamic events.

The first glaciodynamic event is of Saalian age, the second glaciodynamic event is of Saalian or Weichelian age, and finally the deformation of the third dynamic event is related to the main ice advance in the Late Weichselian time, about 20.000 year B.P. (Petersen \& Kronborg, 1990).

Model 2: The second model advocates two glaciodynamic events (major ice advances).

The first glaciodynamic sequence, comprising the glaciofluvial/lacustrine deposits, is related to a Norwegian advance in early Weichselian or in Saalian.

The glaciotectonic deformation is related to a short readvance (mayby a local glacier surge) during the last ice regression in late Weichselian, following the Main ice advance.

It follows that in this model the till was deposited during the ice advance of the main late Weichselian ice.
A readvance may be regarded as one seperate event. The glaciotectonic unit representing this event could thus include all the curved features measured at the exposures at Silstrup, Stærhøj, Skærbæk and Skarrehage (Gry, 1979; Pedersen, 1989b).

The ice push is accordingly related to one local ice tongue moving along the depressions of the Limfjord, and it might show different ice push directions during the same ice advance.

The till at Hanklit was correlated to a till at the nearby "Feggeklit" by Hundahl (1988). The till at Feggeklit was overlying a glaciolacustrine deposit, which has been thermo-luminesence dated to approx. 20.000 BP.

The ice advance related to this till should then be younger than 20.000 years, implying that the till correlates with the "Mid Danish Till Formation" (Houmark-Nielsen, 1987), which was deposited during the Main Advance in late Weichel, thus favouring model 2.

Correlations between the two tills on basis of the finegravel content alone are however questionable considering the distance and the glaciotectonic deformations at Feggeklit (Pedersen, 1993), and a second stratigraphy might therefore be considered in respect of model 1.

No discordant till has been found covering the Hanklit Thrust Fault Complex as evidence for ice transgressing the area, but as the uppermost $15 \mathrm{~m}$ of Quaternary deposits on the Hanklit Thrust Sheet has been eroded away, such a till might have existed before the erosion.

\section{Conclusion:}

We favour model 1, where the Quaternary sediments at Hanklit belong to earlier glaciodynamic sequences, and the glaciotectonic unit, which include the main thrust fault deformation, is related to the glaciodynamic event that includes the advance of the late Weichselian Norwegian Ice which transgressed the area from north towards the Main Stationary Line. The iceflow shifted from north to north-east, and during the regression, superposed deformation affected the thrust fault complexes, with adjustment of the deformation directions as may be seen in Skarrehage and Ejerslev mo-clay pits (Pedersen, 1989b, 1990a). 


\section{Summary and conclusions}

Hanklit is part of a major push-ridge complex, which forms the elongated hills on northern Mors along the coast of Thisted Bredning.

The Hanklit Thrust Fault Complex is an impressive example of an imbricate thrust fault complex formed by a single progressive deformation, caused by the gravity spreading of an advancing glacier.

The thrusting involves three thrust-sheets consisting of both glacigenic sediments and Palaeogene diatomite, which has been dislocated by a glacier moving from the north towards the south.

A geoelectrical investigation facilitated a three-dimesional model of the thrust fault complex. This model documents that the extension of the Hanklit Thrust Sheet is more than $1 \mathrm{~km}$ to the east, and that the glaciofluvial top unit on the thrust sheet thins out towards the east.

The construction of a balanced cross-section provided the basis for a model of the glaciotectonic development of the thrust fault complex, which is displayed in four stages in the sequential cartoon (fig. 17).

1. In the initial stage of deformation the main fractures are formed due to the stress built up along the front of the advancing glacier. Shear joints and reverse faults start to develop, and the sediments are slightly bent.

2. During the second stage the Salgerhøj Thrust Sheet is thrust towards the foreland, and the nose of this thrust sheet becomes an overturned anticline.

3. In the third stage the major displacement along the Hanklit Thrust Fault took place. During the passage of the foot-wall ramp bending of the sediments appeared, and a set of normal faults developed, which were further displaced into the frontal part of the thrust sheet. On the "back" of the Hanklit Thrust Sheet the frontal anticline of the Salgerhøj Thrust Sheet was adjusted by parasitic folding of the uppermost glacigenic sediments.

In the thrust zone between the Hanklit Thrust Sheet and the Gullerup Thrust Sheet structures related to high pore pressure developed in the soft, partly brecciated, sediments.

4. Finally the nose of the Hanklit Thrust sheet is recumbently folded. In the core of the large anticline reverse faults parallel to the axial plane were formed, and the layer including the calcareous concretion and ash layer +130 in the uppermost part of the Fur formation is inhomogeneously folded.

The reconstruction and balancing of the cross-section shows a shortening of the thrust complex to be about $40 \%$.

Three glaciodynamic events have affected the area.

The first one is related to the glaciofluvial deposits and to the fracturing and jointing in the upper part of the Fur Formation sediments.

The second event are related to a till unit and the third glaciodynamic event is represented by the glaciotectonic unit including the thrust fault complex.

Finally if is suggested that the extensional faults in the lower part of the Hanklit Thrust Sheet represent pre-Quaternary Tectonics related to basin subsidence in a depression between elevating salt structures. 


\section{Acknowledgements}

This paper was refereed by dr. David Croot, dr James $S$. Aber and dr. Michael Houmark-Nielsen, who offered many helpful suggestions and contributed a number of stimulating arguments, that clarified the text.

Dr. David Croot is especially thanked for correcting the English text.
Thanks are also directed to Helle Zetterwall and Benny Schark, DGU, for drafting the figures.

K.E.S. Klint wants to thank Kjell Erik Hansen for enthusiastic fieldassistance, Lea Holstein for patient assistance in the laboratory, and Pia Kaae for private support during the Hanklit project. 


\section{References}

Aber, J.S., Croot, D.G \& Fenton, M.M., 1989: Glacioteconic Landforms and structures. Kluwer Academic Pulishers. Dordrect, The Netherlands $200 \mathrm{p}$.

Andersen, S. A., 1944: Moleret og de Vulkanske askelag: In: Det Danske Landskabs Historie. Bind 1., Undergrunden: pp. 391-415.

Banham, P.H., 1988: Thin-skinned glaciotectonic structures. In: Croo G. C., (ed.) Glaciotectonics, Form and processes, Balkema, Rotterdam.

Berthelsen, A., 1978: The methodology of kinetostratigraphy as applied to glacial geology. Bull.geol. Soc.Denmark 27, special issue, pp. 25-38

Berthelsen, A, 1979: Recumbent folds and boudinage structures forme by glacial shear: An example of gravity tectonics. In: Linden , W.J.M van der (ed.): Van Bemmelen and his search for harmony. Geologie en Mijnbouw 58, pp. 253-260.

Bonde, N., 1979: Palaeoenvironment in the "North Sea" as indicated by the fish bearing Mo clay deposit (Paleocene/Eocene), Denmark. Meddel. Werkgrp. tert. kvart. Geol. 16: 3-16.

Boyer, S. E. \& Elliott, D., 1982: Thrust systems. Am. Assoc. Petrol Geol. 66, pp. 1196-1230.

Butler, R. W. H., 1987: Thrust sequences. Journ. Geol. Soc., London, 144, pp. 619-634.

Bøggild, O.B., 1918: Den vulkanske aske i moleret. Danm. Geol Unders. 2 Rk, $33-84$ p.

Clarke, G.K.C. \& Blake E.W., 1991: Geometric and termal evolution of a surge-type glacier, Yokon Territory, Canada, 1969-89. Journ Glaciology 37 No. 125 , pp. $158-169$

Croot, D.G., 1987: Glacio-tectonic structures: A mesoscale model of thin skinned thrust sheets. Journ Structural Geology 9: pp. 797-808.

Croot, D.G., 1988a: Morphological, structural and mechanical analysis of neoglacial ice-pushed ridges in Iceland. In: Croot G.C., (ed.) Glaciotec tonics Form an processes, Croot G. C., (ed.) Balkema, Rotterdam pp 33-48.

Croot, D.G., 1988b: Glaciotectonics and surging glaciers; A correlation based on Vestspitsbergen, Svalbard. In: Croot G.C., (ed.) Glaciotectonice, Form and processes, Balkema, Rotterdam. pp. 49-62.

Dahlström, 1970: Balanced cross sections. Canadian Journ. Earth Scence., 6 pp. $743-757$.

Ditlefsen, C.,1987: En kvartærgeologisk undersøgelse på Thyholm Dansk geol. Foren. Årsskrift for 1987-89, pp. 55-69.

Ehlers, J., 1979: Fine Gravel Analyses after the Dutch Method as testedout on Ristinge Klint, Denmark. Bull geol. Soc. Denmark, vol. 27 pp. 157-165.

Gry, H., 1940: De istektoniske forhold i molerområdet. Meddelelser Dansk geologisk Forening. 9, pp. 586-627.

Gry, H., 1979: Beskrivelser til geologisk kort over Danmark, kortbladetLøgstør, Kvartære aflejringer. Danm. Geol. unders., I Rk. 26, 58 p.

Gry, H., Hansen, K., Andersen, S.A., Madsen, V., Nordmann, V,. \& Larsen, G,. 1941: Diskussion om vore dislocerede Klinters dannelse. Meddr. Dansk geol. Foren. pp. 39-51.

Hansen, J. M. \& Håkansson, E., 1980: Thistedstrukturens geologi et "neotektonisk" skoleeksempel. Dansk geol. Foren. Årsskrift for 1979,pp. 131-140

Hossack, J. R., 1979: The Use of balanced Cross-sections in the calculon of orogenic contraction: a review. Journ. Geol. Soc. Lond. 136.705 711

Houmark-Nielsen, M. 1987: Pleistocene stratigraphy and glacial history of the central part of Denmark. Bull geol. Soc. Denmark, vol. 36, pp. $189 \mathrm{p}$.

Hundahl, M., 1988: En glacialgeologisk undersøgelse af kystklinterne omkring Thisted Bredning. Unpubl. Master Thesis, University of Århus, Denmark.

Håkansson, E. \& Sjørring, S. 1982: Et molerprofil i kystklinten ved Salgerhøj, Mors. Dansk Greol. Foren. Årsskrift 1981: pp. 131-134.

Japsen, P,.1992: Landhævningerne i Sen Kridt og Tertiær i det nordlige Danmark. Dansk geol. Foren., Årsskrift for 1990-91, p. 169-182.

Jensen, K.E.S.K., 1992: En geologisk undersøgelse af et glacialtektonisk disloceret randmorænestrøg ved Hanklit på Nordmors. Unpubl. Master Thesis. University of Copenhagen

Jensen, K.E.S.K \& Pedersen S.A.S., 1989: En undersøgelse af de geoelek- triske forhold i molers området. Danm. geol. Unders. Intern rap. nr.44. Jensen, J.B., \& Knudsen, K.L. 1984: Kvartærstratigrafiske undersøgelse ved Gyldendal og Kås Hoved i det vestlige Limfjorden omrăde. Dansk geol. Foren, Årsskrift for 1983 pp. $35-54$.

Jessen, A., 1918: Vendsyssels geologi. Danm. geol. Unders. IV Rk. 2, 195p.

Jessen, A., 1931: Lønstrup klint. - Danm. Geol. Unders. II Rk. Nr, 49

Larsen G. \& Baumann J., 1982: Træk af Mors salthorstens udvikling Dansk geol. Foren. Årsskrift for 1981, pp. 151-155.

Madirazza, I., 1990: Late Triassic tectonic evolution in northwest Jutland, Denmark. Bull. geol. Soc. Denmark, 38, pp. 77-84.

Meier, M.F. \& Post A., 1969: What are glacier surges? Canadian Journ.of Earth Sciencees, 6, pp. 807-817.

Milthers, V. 1909: Scandinavian Indicator Boulders in Quaternary Deposits. Danm. Geol. Unders. I Rk. No. 11291 p.

Molerindvinding på Mors 1985: Miljøministeriet, Frednings-Styrelsen Viborg Amtsråd, Morsø Kommune og Skamol A/S, 91 p.

Nielsen, O.B., \& Heilmann-Clausen, C. 1988: Palaeogene volcanism: The sedimentary record in Denmark. In: Morton, A.C. \& Parson L.M.(eds.): Early Tertiary Volcanism and the opening of the NE Atlantic. Geol. Soc. London Spec. Publ. No. 33, pp. 395-405.

Noe-Nygaard, A 1991: Larvikiter i kvaderstenskirker. Spec. Publ. Geol Surv. Denmark, $32 \mathrm{p}$.

Pedersen, G.K., 1981: Anoxic events during sedimentation of a Palaeogene diatomite in Denmark. Sedimentology 28; pp. 487-504

Pedersen, G. K. \& Surlyk, F., 1983: The Fur Formation, a late Paleocene ash-bearing diatomite from northern Denmark. Bull. geol. Soc. Denmark. 32, pp. 43-65.

Pedersen S.A.S, 1987: Comparative studies of gravity tectonics in Quaternary sediments and sedimentary rocks related to fold belts. In: Jones, M.E. \& Preston, R. M. F. (eds): Deformation of sediments and sedimentary rocks. Geolo. Soc. London Spec. Publication no. 29, pp. 165-180.

Pedersen, S.A.S.,1989a: Map of Quaternary deposits in Denmark 1:200.000, Nordjylland. Geol. Surv. of Denmark.

Pedersen, S.A.S., 1989b: Strukturgeologi ved Skarrehage. Danm. Geol Unders. Intern rapport nr. 19.

Pedersen S.A.S., 1990: Landet omkring molerhavet. Varv no. 21990 , pp.47-58.

Pedersen S.A.S., 1992a: Strukturel unders $\emptyset$ gelse af Ejerslev molerfelt Danm. Geol.Unders. Intern rapport nr. 11 1992, 25 p. Pedersen, S.A.S., 1992b: Landslide. Varv no. 4 1992, pp. 121-128.

Pedersen, S.A.S. 1993: The Glaciodynamic Event and Glaciotectonic Sequence. In: Aber J.S., (ed.) Glaciotectonics and Mapping Glacial Deposits, Canadian Plains Research Center, University of Regina, pp 67-85.

Pedersen, S.A.S. \& Petersen K.S., 1985a: Forkomsten af sandfyldte, tektonisk betingede, iskilestrukturer i moleret på Fur. Intern rapport nr. 32 Danm. Geol. Unders. 26p.

Pedersen S.A.S. \& Petersen, K.S. ,1985b: Strukturgeologisk unders $\emptyset$ gelse af Stærhøj, Nordvest Mors.Danm.Geol.Unders.26p. Intern rapport nr.7

Pedersen, S.A.S., \& Petersen K.S. \& Rasmussen L.A., 1988: Observations on glaciodynamic structures at the Main Stationary Line in western Jutland, Denmark. In: Croot G. C., (ed.) Glaciotectonics Form and pro-cesses, Balkema, Rotterdam, pp. 177-184.

Pedersen, S.A.S., Foged, N. \& Frederiksen, J. 1989: Extent and econmic significance of landslides in Denmark, Faroe Islands and Greenland. In:Brabb \& Harrod (eds.): Landslides: Extent and economic significance. Balkema, Rotterdam, pp. 153-156.

Pedersen, S.A.S. \& Petersen,K.S.,1990: NØ-Sallings geologi.Danm.Geol. Unders. Intern rapp. 531990,25 p.

Petersen, K.S. \& Kronborg, C.K. 1990: Late Pleistocene history of the in land glaciation in Denmark. In: Frunzel, B. (ed.): Probleme der letzen 130.000 jahre. Paläoklimaforschung, Bd. 1, pp. 331-342.

Suppe, J., 1985: Principles of structural geology. Prentice-Hall,Inc. New Jersey, $425 \mathrm{p}$

Ussing, N. V., 1913: Danmarks Geologi i almentfatteligt Omrids. Danm. Geol. Unders., 3 Rk., nr.2. 
This paper presents glaciotectonic features of Hanklit, Mors, northern Denmark.

Thin-skinned thrust fault structures are described, and a structural analysis of the internal structures of a lage composite ridge is presented.

A balanced cross-section of the thrust fault complex forms the basis for the interpretation of glaciotectonic development. Different models for deformation of the Hanklit Thrust Fault complex are discussed, and a model of glaciodynamic overprint on pre-glacial extensional fault structures is favoured. The preferred model involves proglacial deformation related to Late Weischelian glaciation. 